\title{
RULE 24 NOTWITHSTANDING: WHY ARTICLE III SHOULD NOT LIMIT INTERVENTION OF RIGHT
}

\author{
ZACHARY N. FERGUSON $\dagger$
}

\begin{abstract}
The Supreme Court recently decided in Town of Chester v. Laroe Estates, Inc. that intervenors of right under Federal Rule of Civil Procedure 24(a)(2) must demonstrate independent Article III standing when they pursue relief different from that requested by an original plaintiff. This decision resolved, in part, a decades-long controversy among the Courts of Appeals over the proper relationship between Rule 24 intervention and Article III standing that the Court first acknowledged in Diamond v. Charles. But the Court's narrow decision in Town of Chester hardly disposed of the controversy, and Courts of Appeals are still free to require standing of defendant-intervenors and, it stands to reason, plaintiff-intervenors even if they do not pursue different relief.

With this debate yet unresolved, this Note takes a less conventional approach. In addition to arguing that the Supreme Court's precedents implicitly resolved this question before Town of Chester, this Note argues that the nature of judicial decisions raises two concerns that a liberal application of Rule 24(a)(2) would mitigate. First, this Note argues that stare decisis limits the right of litigants to be heard on the merits of their claims and defenses in a way that undermines the principles of due process. Second, this Note argues that the process of judicial decisionmaking is fraught with potential epistemic problems that can produce suboptimal legal rules. After considering these two concerns, this Note argues that Rule 24(a)(2) is a better and more practical way to mitigate these problems than are Rule 24(a)(2)'s alternatives.
\end{abstract}

\section{INTRODUCTION}

In 2007, a challenge to Indiana's voter identification law came before the Seventh Circuit in Crawford v. Marion County Election

Copyright @ 2017 Zachary N. Ferguson.

$\dagger$ Duke University School of Law, J.D. expected 2018. 
Board. ${ }^{1}$ Writing for the majority, Judge Richard Posner defended the identification laws as imposing merely "ordinary and widespread burdens" 2 and accepted the trial judge's finding that the data on voter suppression presented by the plaintiff-appellants were "totally unreliable." 3 Because no plaintiff had joined the suit alleging that they "intend[ed] not to vote because of the new law," Judge Posner reasoned that "the motivation for the suit is simply that the law may require the Democratic Party and other organizational plaintiffs to work harder to get every last one of their supporters to the polls." ${ }^{.4}$ The plaintiffs, Judge Posner reckoned, were engaged in a politically motivated assault on a reasonable electoral regulation. On appeal to the Supreme Court, ${ }^{5}$ the plaintiffs-turned-petitioners lost in a 6-3 decision. The Court, like Judge Posner, found " $[\mathrm{t}]$ he universally applicable requirements of Indiana's voter-identification law [to be] eminently reasonable." 6

Seven years later, a similar voter identification law came before the Seventh Circuit. ${ }^{7}$ Writing for the majority, Judge Frank Easterbrook-Judge Posner's intellectual frenemy-concluded that the regulation was "amply justified by the valid interest in protecting the integrity and reliability of the electoral process." ${ }^{8}$ But then the unexpected happened: a judge on the Seventh Circuit requested a vote for a rehearing en banc, which failed by an equally divided vote. ${ }^{9}$ Unlike many rehearing orders, this one drew a fire-and-brimstone dissent from five of the acting judges. The dissenting judges excoriated the majority for its reliance on "downright goofy"10 evidence of voter fraud, noting that "[e]ven Fox News, whose passion for conservative causes has never been questioned, acknowledges that 'Voter ID Laws Target Rarely Occurring Voter Fraud.""11 "[I]f there is no actual

\footnotetext{
1. Crawford v. Marion Cty. Election Bd., 472 F.3d 949 (7th Cir. 2007), aff'd, 553 U.S. 181 (2008)

2. Id. at 954

3. Id. at 952 .

4. Id.

5. Crawford v. Marion Cty. Election Bd., 553 U.S. 181 (2008).

6. Id. at 209 (Scalia, J., concurring).

7. Frank v. Walker, 768 F.3d 744 (7th Cir. 2014).

8. Id. at 755 (quoting Crawford, 553 U.S. at 204).

9. Frank v. Walker, 773 F.3d 783, 783 (7th Cir. 2014) (5-5 vote).

10. Id. at 791 (Posner, J., dissenting from denial of rehearing in banc).

11. Id. (citing Voter ID Laws Target Rarely Occurring Voter Fraud, Fox NEws: Politics (Sept. 24, 2011), http://www.foxnews.com/politics/2011/09/24/voter-id-laws-target-rarelyoccurring-voter-fraud.html [https://perma.cc/7SAQ-CEW3]).
} 
danger of [voter identification] fraud," the dissent argued, "[t]here is only one motivation for imposing burdens on voting ... and that is to discourage voting by persons likely to vote against the party responsible for imposing the burdens." ${ }^{12}$ Crawford's presumptively neutral voter identification laws were now, according to the dissent, presumptively political.

The dissent was shocking for a number of reasons, not the least of which was its comparison of the Wisconsin law to a literal witch hunt. ${ }^{13}$ Perhaps most shocking was the identity of the dissent's author, Judge Richard Posner, who had teed up the Supreme Court's affirmation of a similar voter identification law only seven years earlier in Crawford. Facing critics' charges that he had recanted his position on voter identification laws, Judge Posner later explained his reversal on empirical, as opposed to legal or normative, grounds: he simply did not have enough information in Crawford to sniff out the Indiana statute's political motivation. ${ }^{14}$ "[I]n common with many other judges," Judge Posner explained, "I could not be confident that [my opinion] was right, since I am one of the judges who doesn't understand the electoral process sufficiently well to be able to gauge the consequences of decisions dealing with that process." 15

Federal judges often confront cases asking them to set precedent with less-than-complete information. ${ }^{16}$ Because of the function of stare decisis in the federal judiciary, these judgments often have far-reaching and functionally permanent consequences; Crawford, for instance, is unlikely to be overturned in the near future and, given its affirmation by the Supreme Court, the opinion binds parties not even remotely connected to the original litigation. At the trial level, the Federal Rules of Civil Procedure provide a partial remedy. Rule 24(a)(2) offers a party the right to intervene in ongoing litigation provided that the party meet three conditions: (1) the applicant has an interest implicated by the suit that (2) will be impaired unless the existing party adequately

12. Id. at 796 .

13. Id. at 795 ("As there is no evidence that voter impersonation fraud is a problem, how can the fact that a legislature says it's a problem turn it into one? If the Wisconsin legislature says witches are a problem, shall Wisconsin courts be permitted to conduct witch trials?")

14. Richard A. Posner, I Did Not 'Recant' on Voter ID Laws, New RePUBLIC (Oct. 27, 2013), https://newrepublic.com/article/115363/richard-posner-i-did-not-recant-my-opinion-voter-id [https://perma.cc/QW7X-CNKS].

15. Id.

16. For a discussion of the epistemic constraints of judicial decisionmaking, see infra Part II.B.2 . 
represents it, and (3) the existing party is inadequately representing the interest. ${ }^{17}$ Thus, a party who might be affected by a given case-even if the effect is somewhat speculative ${ }^{18}$ - has the right under Rule 24(a)(2) to make arguments the original party either refused or was incompetent to make, or to present additional evidence (of voter fraud, for example). ${ }^{19}$

Although the text of Rule 24(a)(2) lays out only three requirements, several circuits have engrafted Article III's standing requirements onto the Rule, ${ }^{20}$ creating an additional hurdle to thirdparty intervention. As a result, federal courts in these circuits are denied potentially relevant information from parties not immediately bound by a given case. Those same parties are denied the ability to represent their interests in precedent-setting litigation, and because lower federal courts adhere rigidly to stare decisis, these parties are effectively prevented from challenging precedents once set.

Academic commentary on the Rule 24(a)(2) circuit split has focused on whether Article III requires would-be intervenors to establish standing. ${ }^{21}$ After declining on several occasions to address this issue, ${ }^{22}$ the Supreme Court recently revisited this question in Town of

17. FED. R. CIV. P. 24(a)(2).

18. For cases that recognize adverse stare decisis effect as a cognizable interest under Rule 24(a)(2), see infra note 47 and accompanying text.

19. For example, the defendant-intervenors in Grutter v. Bollinger-a pro-affirmative action nonprofit and seventeen minority students seeking admission to the University of Michiganargued that they would advance certain defenses of affirmative action that the University, subject to "internal and external institutional pressures," could not. Grutter v. Bollinger, 188 F.3d 394, 400 (6th Cir. 1999). The defendant-intervenors also argued that, because an adverse ruling would harm the University less than it would them, the University alone would "not defend the case as vigorously as [would] the proposed intervenors." Id.

20. For cases in which courts of appeals have held that intervenors under Rule 24(a)(2) need to show Article III standing, see infra note 79.

21. See, e.g., Carl Tobias, Standing to Intervene, 1991 WIS. L. REV. 415, 463 (1991) (suggesting a "pragmatic, equitable recalibration" of the approach to standing and Rule 24); Amy M. Gardner, Comment, An Attempt to Intervene in the Confusion: Standing Requirements for Rule 24 Intervenors, 69 U. CHI. L. REV. 681, 684 (2002) (arguing that intervention should be allowed so long as "the original parties remain in the suit and meet the requirements for standing"); Juliet Johnson Karastelev, Note, On the Outside Seeking in: Must Intervenors Demonstrate Standing To Join a Lawsuit?, 52 DUKE L.J. 455, 480 (2002) (arguing that requiring Article III standing of an intervenor should depend on the type of relief sought); Kerry C. White, Note, Rule 24(a) Intervention of Right: Why the Federal Courts Should Require Standing to Intervene, 36 LOY. L.A. L. REV. 527, 530 (2002) (arguing in favor of applying standing requirements to intervenors).

22. See, e.g., Diamond v. Charles, 476 U.S. 54, 68-69 (1986) ("We need not decide today whether a party seeking to intervene before a district court must satisfy not only the requirements of Rule 24(a)(2), but also the requirements of Art. III.”). 
Chester v. Laroe Estates, Inc. ${ }^{23}$ In a unanimous opinion, the Court narrowly held that intervenors under Rule 24(a)(2) must establish independent standing when the intervenor pursues relief not requested by a plaintiff. ${ }^{24}$ As several commentators have noted, ${ }^{25}$ the result in Town of Chester leaves open the question of whether an intervenor who seeks the same relief as a plaintiff needs to show independent Article III standing. The opinion also leaves unanswered the question of whether intervenors who seek no relief at all-including defendantintervenors, in most cases - need to satisfy Article III standing. With these questions still open, ${ }^{26}$ this Note argues that the quasi-legislative character of judicial decisions and decisionmaking militates against imposing Article III standing on Rule 24(a)(2) intervenors when the intervenors do not request different relief.

Specifically, this Note argues that when judicial decisionmaking creates a quasi-legislative rule, as is the case with most opinions, courts' use of Article III standing to exclude would-be intervenors from this process raises two interrelated concerns. First, excluding additional parties decreases the volume and, potentially, the quality of information entering the process, thereby increasing the probability that the court will generate bad precedent. This is especially true when the original party's representation of a given interest is inadequate, a possibility the text of Rule 24(a)(2) openly acknowledges. ${ }^{27}$ Second, a court's ruling effectively binds all future litigants within its jurisdiction. To varying extents, future litigants are thus denied the opportunity to be heard on the merits of their claims and defenses. Although this

23. Town of Chester v. Laroe Estates, Inc., 137 S. Ct. 1645 (2017)

24. Id. at 1648 .

25. See, e.g., Howard M. Wasserman, Opinion Analysis: Standing, Intervention, and a Narrow Disposition, SCOTUSBLOG (June 5, 2017, 2:14 PM), http://www.scotusblog.com/2017/06/opinionanalysis-standing-intervention-narrow-disposition [https://perma.cc/H2WQ-4CJZ] ("The court's narrow decision did not expressly address ... [whether] an intervenor need[s to] show standing if its litigation activities do not extend beyond asserting the same claim for the same remedies as the original plaintiff.").

26. The Court's opinion left open the possibility that standing could be required of intervenors seeking the same relief. Town of Chester, 137 S. Ct. at 1647 ("Thus, at the least, an intervenor of right must demonstrate Article III standing when it seeks additional relief beyond that which the plaintiff requests." (emphasis added)).

27. See FED. R. CIV. P. 24(a)(2) (entitling an interested party to intervene if their interest will be impaired "unless existing parties adequately represent that interest"); FED. R. CIV. P. 24(a)(2) advisory committee's note to the 1966 amendment ("The general purpose of original Rule 24(a)(2) was to entitle an absentee, purportedly represented by a party, to intervene in the action if he could establish with fair probability that the representation was inadequate.”). 
denial does not violate procedural due process, it does undermine the principles underlying the doctrine.

This Note proceeds in three parts. Part I examines the circuit split, arguing that, despite Supreme Court rulings suggesting some resolution, the debate as to whether Article III applies or ought to apply to Rule 24(a)(2) intervention remains open. To the extent that the Supreme Court has considered the issue, its precedents suggest that Rule 24(a)(2) intervenors requesting the same relief need not demonstrate independent Article III standing. Part II considers the scope and effect of stare decisis, arguing that the doctrine - if not for Rule 24(a)(2) intervention-denies the federal judiciary potentially important information and denies would-be intervenors the ability to fully defend their interests. For instance, the Seventh Circuit is among the minority of circuits requiring independent Article III standing of Rule 24(a)(2) intervenors. ${ }^{28}$ Were it otherwise, the court in Crawford could have benefited from the intervention of public interest groups specializing in election law, such as the Brennan Center for Justice, which was relegated to filing an amicus brief. ${ }^{29}$ Finally, Part III evaluates the alternatives to Rule 24(a)(2) intervention-namely, the amicus brief and the political process - and ultimately argues that Rule 24 without a standing requirement best guards against the process errors discussed in Part II.

\section{The PRinCiPles of ARTICle III StANDing, Rule 24(A)(2), AND THE CIRCUIT SPLIT}

While the majority of this Note focuses on the information- and equity-related arguments against engrafting Article III's standing requirement onto Rule 24(a)(2) intervention, this Part focuses on the doctrine underlying Rule 24 intervention and standing, and the purposes both are meant to serve. This Part also argues that recent developments in standing jurisprudence cast serious doubt on some courts' arguments for requiring Article III standing of Rule 24(a)(2) intervenors.

\footnotetext{
28. See, e.g., City of Chicago v. FEMA, 660 F.3d 980, 984-85 (7th Cir. 2011).

29. For a discussion of the Brennan Center's brief in Crawford, see infra note 232 and accompanying text.
} 


\section{A. Rule 24(a)(2), Then and Now}

Though it has some antecedents in Roman and civil law, the right to intervene in ongoing litigation is a relatively recent development in Anglo-American jurisprudence. ${ }^{30}$ As with compulsory joinder under Rule 19 and class action under Rule 23, Rule 24 intervention arose in response to the modern recognition that "a lawsuit often is not merely a private fight and will have implications on those not named as parties." ${ }^{31}$ Rule 24(b), the "permissive" subdivision of Rule 24, grants judges discretion to allow intervention by a party who has a "conditional right to intervene by a federal statute" 32 or "a claim or defense that shares with the main action a common question of law or fact." ${ }^{33}$ Rule 24(a)(2), by contrast, allows intervention "of right," removing judges' discretion to disallow intervention so long as the would-be intervenor meets the Rule's conditions. ${ }^{34}$ After its last substantive amendment in 1966, Rule 24(a)(2) reads, in relevant part:

On timely motion, the court must permit anyone to intervene who ... claims an interest relating to the property or transaction that is the subject of the action, and is so situated that disposing of the action may as a practical matter impair or impede the movant's ability to protect its interest, unless existing parties adequately represent that interest. ${ }^{35}$

It is worth noting that Rule 24(a)(2) emphasizes the "practical" nature of the impediment or impairment that triggers intervention of right. The pre-1966 Rule 24(a)(2) required that "the applicant [actually or potentially] be bound by a judgment in the action" 36 before she had the right to intervene. Though a minority of courts interpreted "bound" to mean practical prejudice, ${ }^{37}$ a 1961 Supreme Court ruling

30. See James Wm. Moore \& Edward H. Levi, Federal Intervention I. The Right To Intervene and Reorganization, 45 YALE L.J. 565, 568-70 (1935).

31. 7C Charles Alan Wright, arthur R. Miller \& Mary Kay Kane, Federal PRACTICE AND PROCEDURE $§ 1901$, at 258 (3d ed. 2007) [hereinafter 7C Wright \& Miller].

32. FED. R. CIV. P. 24(b)(1)(A).

33. FED. R. CIV. P. 24(b)(1)(B).

34. See 7C WRIGHT \& MiLlER, supra note 31, § 1902, at 261 (noting that, unlike Rule 24(b)'s appeal to judicial discretion, Rule 24(a)(2) "seems to pose only a question of law").

35. FED. R. CIV. P. 24(a)(2) (emphasis added).

36. FED. R. CIV. P. 24(a)(2) advisory committee's note to the 1966 amendment.

37. See, e.g., Atlantic Ref. Co. v. Standard Oil Co., 304 F.2d 387, 394 (D.C. Cir. 1962) ("We are of the opinion... [that] the res judicata test for determining whether an applicant for intervention in the action will be bound by the judgment therein is unworkable and inappropriate."). This was a fairly squishy standard. The Third Circuit, for example, required only 
affirmed the majority interpretation of "bound" as analogous to res judicata. $^{38}$ The 1966 amendment intentionally broadened harm cognizable under Rule 24(a)(2) to include not only res judicata, but "practical" impairment as well. ${ }^{39}$ Furthermore, the 1966 amendment redefined the "interest" required from "an interest in property" to one also recognizing "less tangible interests." ${ }^{40}$ The aggregate force of these changes was to "abandon[] formalistic restrictions in favor of 'practical considerations' to allow courts to reach pragmatic solutions to intervention problems." ${ }^{41}$ As a result, the decade following the amendment saw a dramatic increase in public interest litigation - the reformed Rule 24(a)(2) had become better equipped to recognize the "relatively intangible, abstract" interests these organizations represent. ${ }^{42}$

With greater scope came greater confusion. Whereas the more limited remit of the pre-1966 Rule lent itself to relatively straightforward judicial application, ${ }^{43}$ the liberalized post-1966 Rule has proven considerably harder to apply. ${ }^{44}$ In particular, the bounds of what can be considered a Rule 24(a)(2) "interest" are ill-defined, ${ }^{45}$ and the Supreme Court's jurisprudence on this point has provided unclear guidance. ${ }^{46}$

that an applicant's rights would be "affected" by an adverse decision. Mack v. Passaic Nat'l Bank \& Trust Co., 150 F.2d 474, 477 (3d Cir. 1945).

38. See Sam Fox Pub. Co. v. United States, 366 U.S. 683, 689 (1961) ("We regard it as fully settled that a person whose private interests coincide with the public interest in government antitrust litigation is nonetheless not bound by the eventuality of such litigation, and hence may not, as of right, intervene in it.").

39. See FED. R. CIV. P. 24(a)(2) advisory committee's note to the 1966 amendment ("The [amended rule] imports practical considerations, and the deletion of the 'bound' language similarly frees the rule from undue preoccupation with strict considerations of res judicata.").

40. Susan Bandes, The Idea of a Case, 42 STAN. L. REV. 227, 252-53 n.164 (1990). But see Tobias, supra note 21, at 429-32 (noting that the intent behind the 1966 amendment "remains unclear and controversial").

41. United States v. Hooker Chems. \& Plastics Corp., 749 F.2d 968, 983 (2d Cir. 1984); see also 7C WRIGHT \& MILLER, supra note 31, § 1901, at 257-60 (noting that Rules 19, 23, and 24 are "an effort to strike a balance between varying interests").

42. Tobias, supra note 21 , at 419.

43. Id. at 422 .

44. Id. at 432 .

45. See 7C WRIGHT \& MiLlER, supra note 31, § 1908.1, at 300 ("There is not any clear definition of the nature of the 'interest relating to the property or transaction that is the subject of action' that is required for intervention of right.").

46. See id. ("The Supreme Court has spoken to the question [of what constitutes an 'interest' under Rule 24] twice since the rule was amended in 1966, but those cases generally have been limited to their somewhat unique facts.”). 
What is certain is that the post-1966 Rule 24(a)(2) opens the door to parties attempting to protect interests that would not normally constitute the "concrete" and "actual or imminent" injury Article III standing requires. For instance, numerous circuits have recognized the potential for adverse precedent as a cognizable interest under Rule $24(\mathrm{a})(2) \cdot{ }^{47}$

\section{B. Article III Standing}

In marked contrast to Rule 24's court-opening force, the standing requirement of Article III determines "whether the litigant is entitled to have the court decide the merits [of his dispute]." ${ }^{48}$ Article III standing derives from the Constitution's Case or Controversy Clause, ${ }^{49}$ which establishes the scope of the federal judiciary's jurisdiction. The "irreducible minimum" of Article III standing is: (1) a distinct and actual injury that is (2) fairly traceable to the conduct of the defendant and that (3) will be redressed if the Court renders a favorable decision. ${ }^{50}$

47. See, e.g., Stone v. First Union Corp., 371 F.3d 1305, 1309-10 (11th Cir. 2004) ("[T]he potential for negative stare decisis effect 'may supply that practical disadvantage which warrants intervention of right."' (quoting Chiles v. Thornburgh, 865 F.2d 1197, 1214 (11th Cir. 1989))); Georgia v. U.S. Army Corps of Eng'rs, 302 F.3d 1242, 1258 (11th Cir. 2002) (same); Utah Ass'n of Ctys. v. Clinton, 255 F.3d 1246, 1254 (10th Cir. 2001) ("[T]he stare decisis effect of the district court's judgment is sufficient impairment for intervention under Rule 24(a)(2)." (quoting Coal. of Ariz./N.M. Ctys. for Stable Econ. Growth v. Dep't of Interior, 100 F.3d 837, 844 (10th Cir. 2001))); Sierra Club v. Glickman, 82 F.3d 106, 109-10 (5th Cir. 1996) (per curiam) ("[T]he stare decisis effect of an adverse judgment constitutes a sufficient impairment to compel intervention."); Oneida Indian Nation v. New York, 732 F.2d 261, 265 (2d Cir. 1984) (granting intervention "primarily to guard against encountering the stare decisis effect of a decision in favor of the defendants"); Nuesse v. Camp, 385 F.2d 694, 702 (D.C. Cir. 1967) ("We think that under [the post-1966-amendment Rule 24(a)(2)] stare decisis principles may in some cases supply the practical disadvantage that warrants intervention as of right.”). But see Sec. Inv'r Prot. Corp. v. Bernard L. Madoff Inv. Sec. L.L.C., 550 B.R. 241, 253 (Bankr. S.D.N.Y. 2016) (suggesting that the court in Nuesse "observed that it would not apply Rule 24 literally to atypical cases such as the one before it").

48. Warth v. Seldin, 422 U.S. 490, 498 (1975).

49. U.S. CONST. art. III, § 2, cl. 1 ("The judicial Power shall extend to all Cases ... arising under this Constitution, the Laws of the United States... [and] to Controversies to which the United States shall be a Party ....”).

50. As the Supreme Court has explained:

[T] he irreducible constitutional minimum of standing contains three elements. First, the plaintiff must have suffered an "injury in fact" - an invasion of a legally protected interest which is (a) concrete and particularized, and (b) "actual or imminent, not 'conjectural' or 'hypothetical.", Second, there must be a causal connection between the injury and the conduct complained of - the injury has to be "fairly ... trace[able] to the challenged action of the defendant, and not ... th[e] result [of] the independent action of some third party not before the court." Third, it must be "likely," as opposed to merely "speculative," that the injury will be "redressed by a favorable decision." 
Standing has also traditionally comprised several prudential limitations,$^{51}$ though the status of prudential standing is now in question. In Lexmark International, Inc. v. Static Control Components, Inc. ${ }^{52}$ the Supreme Court reaffirmed "the principle that 'a federal court's obligation to hear and decide' cases within its jurisdiction 'is virtually unflagging." 53 As a result, "prudential" doctrines not grounded in Article III's Case or Controversy requirement-such as the zone-of-interests test-are now presumptively unconstitutional. ${ }^{54}$ It is difficult to know whether Lexmark signifies the "end of prudential standing," 55 as some academic commentary has suggested. ${ }^{56}$ Regardless, Lexmark can at least be seen to affirm the proposition that, once jurisdiction is established, standing cannot be used as a prudential bar to limit the public's access to the federal judiciary.

Of particular concern to this Note is Lexmark's elevation of the ban on generalized grievances to Article III status. The prohibition on generalized grievances - the adjudication of "abstract questions of wide public significance" 57 - exists "to limit the role of the courts in resolving public disputes." ${ }^{58}$ Whereas Lujan v. Defenders of Wildlife $e^{59}$ had already arguably incorporated the prohibition on generalized

Lujan v. Defs. of Wildlife, 504 U.S. 555, 560-61 (1992) (first alteration added) (quoting Whitmore v. Arkansas, 495 U.S. 149, 155 (1990); then quoting Simon v. Eastern Ky. Welfare Rights Org., 426 U.S. 26, 38, 41-42, 43 (1976)) (citing Allen v. Wright, 468 U.S. 737, 756 (1984); then citing Warth v. Seldin, 422 U.S. 490, 508 (1975); then citing Sierra Club v. Morton, 405 U.S. 727, 740741 n.16 (1972)).

51. See, e.g., Valley Forge Christian Coll. v. Ams. United for Separation of Church \& State, Inc., 454 U.S. 464, 474 (1982) ("Beyond the constitutional requirements, the federal judiciary has also adhered to a set of prudential principles that bear on the question of standing."). The three principles of prudential standing are: (1) the prohibition against asserting the rights of third parties, (2) the prohibition of generalized grievances, and (3) the requirement that a plaintiff's complaint fall within the zone of interests protected by a given statute or constitutional guarantee. See id. at 474-75 (listing and explaining the three principles of prudential standing).

52. Lexmark Int'l, Inc. v. Static Control Components, Inc., 134 S. Ct. 1377 (2014).

53. Id. at 1386 (quoting Sprint Commc'ns, Inc. v. Jacobs, 134 S. Ct. 584, 591 (2013)).

54. See id. at 1387 n.3 (categorizing the ban on generalized grievances as an Article III requirement and declining to decide the "proper place" of third-party standing limitations).

55. Michael Ramsey, Lexmark v. Static Control: The End of Prudential Standing?, ORIGINALISM BLOG (Mar. 27, 2014), http://originalismblog.typepad.com/the-originalism-blog/ 2014/03/lexmark-v-static-control-the-end-of-prudential-standingmichael-ramsey.html [https://per ma.cc/BS77-69B7].

56. For a more nuanced discussion of Lexmark and prudential standing, see generally Ernest A. Young, Prudential Standing After Lexmark International, Inc. v. Static Control Components, Inc., 10 DUKe J. CONST. L. \& PUB. POL'Y 149 (2014).

57. Warth v. Seldin, 422 U.S. 490, 500 (1975).

58. Id.

59. Lujan v. Defenders of Wildlife, 504 U.S. 555 (1992). 
grievances into Article III standing, ${ }^{60}$ Lexmark made clear that the prohibition rests on "constitutional reasons, not "prudential' ones." 61 This represents a further tightening of standing doctrine begun by the Rehnquist Court. ${ }^{62}$ In contrast to the Warren Court's more lenient view of Article III standing, which allowed plaintiffs to bring suits even if they were not demonstrably more injured than the general public, ${ }^{63}$ the modern doctrine of standing requires that a plaintiff have suffered "an invasion of a legally protected interest which is . . . concrete and particularized," ${ }^{64}$ such that she is " directly" affected apart from [her] 'special interest in th[e] subject." ${ }^{65}$ For instance, a plaintiff who seeks under the Endangered Species Act ${ }^{66}$ to challenge a federal project will not have standing merely on the basis of her special interest in a particular endangered species. ${ }^{67}$ But once she forms "concrete plans" to see that species, such as by buying a plane ticket to the project site, ${ }^{69}$ her injury becomes concrete and particularized. Accordingly, such a plaintiff would be well on her way to satisfying the requirements of Article III standing.

At first glance, it is not entirely clear why Rule 24 intervention should require a showing of Article III standing. Quite apart from the fact that Rule 24's text nowhere mentions standing, the requirements of standing are almost antithetical to Rule 24's requirements. Rule 24

60. In Lujan, the Supreme Court explained that, in addition to having a concrete and particularized injury, the plaintiff must be "'directly' affected apart from [her] 'special interest in th[e] subject."' Id. at 563 (second alteration in original) (quoting Sierra Club v. Morton, 405 U.S. 727, 739 (1972)). However, the Court later explained in Elk Grove Unified School District v. Newdow, 542 U.S. 1 (2004) that the prohibition on generalized grievances was part of "prudential standing ... [which is] closely related to Art. III concerns but [is] essentially [a] matter[] of judicial self-governance." Elk Grove Unified Sch. Dist., 542 U.S. at 12.

61. Lexmark Int'l, Inc. v. Static Control Components, Inc., 134 S. Ct. 1377, 1387 n.3 (2014).

62. However, it should be acknowledged that the Roberts Court has liberalized standing in a number of ways as well. See, e.g., Sprint Commc'ns Co. v. APCC Servs., Inc., 554 U.S. 269, 292 (2008) (granting standing to assignees to pursue claims for money owed even when the assignee has promised to remit the proceeds to the assignor); Massachusetts v. EPA, 549 U.S. 497, 535 (2007) (allowing Massachusetts to challenge the EPA's denial of a rulemaking petition); Young, supra note 56, at 157-58 (explaining that Lexmark "may have the unintended consequence of loosening the causation element of constitutional standing").

63. See, e.g., Flast v. Cohen 392 U.S. 83, 100-01 (1968) (finding taxpayer standing sufficient to contest federal funding of parochial schools).

64. Lujan, 504 U.S. at 560.

65. Id. at 563 (second alteration in original) (quoting Sierra Club, 405 U.S. at 735, 739).

66. 16 U.S.C. $\$ 1536$ (2012).

67. Lujan, 504 U.S. at 560.

68. Id. at 564 .

69. Id. at 579 (Kennedy, J., concurring). 
is broad enough to protect "relatively intangible [and] abstract" interests, including the potentially adverse effects of stare decisis; ${ }^{71}$ standing's injury requirement, on the other hand, demands that the plaintiff show she "has sustained or is immediately in danger of sustaining some direct injury' ... [that is] both 'real and immediate,' not 'conjectural' or 'hypothetical."'72 Rule 24 asks whether the plaintiff's interest might be impaired as a result of inadequate representation ${ }^{73}$ which requires a judge to make a predictive, practical determination; standing requires that the there be a "causal connection" between the plaintiff's injury and the defendant's conduct ${ }^{74}$ which requires a judge to make a retrospective empirical and legal determination. Rule 24 requires a showing that the plaintiff's interest will "as a practical matter" be "impair[ed]"; 75 standing's redressability prong requires the plaintiff to show that her requested relief will likely redress, not merely mitigate, her alleged injury. ${ }^{76}$ Perhaps most significant, whereas Rule 24(a)(2) is a filtering mechanism meant to distinguish between parties who are entitled to intervene and parties who are not, Article III standing is a jurisdictional concept that defines and thereby limits the scope of the federal judiciary's power. ${ }^{77}$ Once Article III standing is satisfied by the

70. Tobias, supra note 21, at 419.

71. For cases that recognize adverse stare decisis effect as a cognizable interest under Rule 24(a)(2), see supra note 47 and accompanying text.

72. City of Los Angeles v. Lyons, 461 U.S. 95, 101-02 (1983).

73. See FED. R. CIV. P. 24(a)(2) (entitling an interested party to intervene if their interest will be impaired "unless existing parties adequately represent that interest").

74. Lujan, 504 U.S. at 560.

75. FED. R. CIV. P. 24(a)(2).

76. In Allen v. Wright, 468 U.S. 737 (1984) for instance, the Court denied the parents of black public schoolchildren standing to challenge the IRS's failure to revoke the tax-exempt status of racially discriminatory private schools. Even though plaintiff's "request might have a substantial effect on the desegregation of public schools," the Court denied standing because the children's inability to attend desegregated schools "might not be traceable to IRS violations of the law." Allen, 468 U.S. at 753 n.19.

77. See Town of Chester v. Laroe Estates, Inc., 137 S. Ct. 1645, 1650 (2017) ("[Standing] preserves the 'tripartite structure' of our Federal Government, prevents the Federal Judiciary from 'intrud[ing] upon the powers given to the other branches,' and 'confines the federal courts to a properly judicial role." (second alteration in original) (quoting Spokeo, Inc. v. Robins, 136 S. Ct. 1540, 1547 (2016))); Flast v. Cohen, 392 U.S. 83, 97 (1968) ("Federal judicial power is limited to those disputes which confine federal courts to a role consistent with a system of separated powers and which are traditionally thought to be capable of resolution through the judicial process."); John G. Roberts, Jr., Article III Limits on Statutory Standing, 42 DUKE L.J. 1219, 1220 (1993) ("The legitimacy of an unelected, life-tenured judiciary in our democratic republic is bolstered by the constitutional limitation of that judiciary's power in Article III to actual 'cases' and 'controversies."'). 
original parties, using standing as an additional filter against intervening parties displaces the role of Rule 24(a)(2).

\section{The Minority Circuits' Approaches, Considered}

The majority of circuits allow Rule 24 intervention without a showing of Article III standing. ${ }^{78}$ The minority position-articulated by the Seventh, Eighth, and D.C. circuits-requires that a Rule 24 intervenor satisfy Article III standing. ${ }^{79}$ The minority circuits' position rests on three distinct but interrelated justifications, which I refer to as the categorical approach, the floodgates concern, and the equal footing rationale.

1. The Eighth Circuit's Categorical Approach. The first rationale, articulated by the Eighth Circuit in Mausolf v. Babbitt, ${ }^{80}$ concerns the supposed threat to Article III jurisdiction that intervenors pose. Though the court recognized that "Rule 24(a) speaks to practical concerns . . . [and] promotes the efficient and orderly use of judicial resources by [consolidating litigation]," $" 81$ the Eighth Circuit took the categorical position that "an Article III case or controversy, once joined by intervenors who lack standing, is - put bluntly - no longer an Article III case or controversy." 82

Though it is generally undisputed that federal jurisdiction turns on the invoking party's satisfaction of Article III standing ${ }^{83}$ applying this requirement to all intervening parties presents two issues. First, the consensus among commentators is that only the plaintiff invoking the

78. See, e.g., Laroe Estates, Inc. v. Town of Chester, 828 F.3d 60, 62 (2d Cir. 2016), vacated, 137 S. Ct. 1645 (2017); King v. Governor of New Jersey, 767 F.3d 216, 245-46 (3d Cir. 2014); Perry v. Schwarzenegger, 630 F.3d 898, 905-06 (9th Cir. 2011); City of Herriman v. Bell, 590 F.3d 1176, 1183-84 (10th Cir. 2010); Dillard v. Chilton Cty. Comm'n, 495 F.3d 1324, 1336-37 \& n.10 (11th Cir. 2007); United States v. Tennessee, 260 F.3d 587, 595 (6th Cir. 2001); Ruiz v. Estelle, 161 F.3d 814, 829-30 (5th Cir. 1998).

79. See, e.g., City of Chicago v. FEMA, 660 F.3d 980, 984-85 (7th Cir. 2011); United States v. Metro. St. Louis Sewer Dist., 569 F.3d 829, 833-34, 833 n.2 (8th Cir. 2009); United States v. Philip Morris USA Inc., 566 F.3d 1095, 1145-46 (D.C. Cir. 2009).

80. Mausolf v. Babbitt, 85 F.3d 1295 (8th Cir. 1996).

81. Id. at 1300 .

82. Id.

83. See 13A Charles Alan Wright \& Arthur R. Miller, Federal Practice And PROCEDURE § 3531, at 4-6 (3d ed. 2008) [hereinafter 13A WRIGHT \& MILLER] ("The party focused upon [in standing inquiries] is almost invariably the plaintiff. . . [O]rdinarily the role of defendants is considered only in determining whether they have caused the injury complained of and whether an order directed to them will redress that injury."). 
court's jurisdiction must satisfy Article III standing. ${ }^{84}$ This position accords with Lexmark's interpretation of the purpose behind Article III standing: to determine whether the plaintiff's claim "presents a case or controversy that is properly within federal courts' Article III jurisdiction." ${ }^{85}$ Standing is a subject-matter limitation, and a court's jurisdiction, once vested, cannot be destroyed unless the original case or controversy disappears. ${ }^{86}$ The minority position, by contrast, treats standing as a freestanding set of criteria that all intervenors-even defendants who are not traditionally required to demonstrate standing $^{87}$ - must satisfy.

Second, the Eighth Circuit's bright-line position - that adding any party who lacks Article III standing destroys federal jurisdiction over a case-is irreconcilable with the circuit's treatment of permissive intervention under Rule 24(b). For example, in Flynt v. Lombardi $i^{88}$ the Eighth Circuit allowed an intervenor under Rule 24(b) despite acknowledging that the intervenor lacked Article III standing. ${ }^{89}$ Because the intervenor sought only to unseal legal documents rather than to litigate, the court reasoned that "an independent basis of jurisdiction [was] not required." 90 This approach-examining the intervenor's purpose and determining whether it demands independent standing-contrasts strongly with the Eighth Circuit's approach in Mausolf, in which the inclusion of a party lacking Article III standing destroyed jurisdiction irrespective of the party's motive. ${ }^{91}$ If the Eighth Circuit in Mausolf was correct on this point, Flynt appears incorrectly decided, given that there is no principled distinction

84. See Karastelev, supra note 21 , at $470-71 \&$ n.98 (citing cases and commentary arguing that only the plaintiff needs to have standing to establish a justiciable case or controversy).

85. Lexmark Int'l, Inc. v. Static Control Components, Inc., 134 S. Ct. 1377, 1386 (2014).

86. See Ruiz v. Estelle, 161 F.3d 814, 832 (5th Cir. 1998) ("Once a valid Article III case-orcontroversy is present, the court's jurisdiction vests. The presence of additional parties, although they alone could independently not satisfy Article III's requirements, does not of itself destroy jurisdiction already established."). For Supreme Court precedent suggesting that jurisdiction is not destroyed by the presence of parties lacking Article III standing, see infra Part I.D.

87. See Valley Forge Christian Coll. v. Ams. United for Separation of Church \& State, Inc., 454 U.S. 464, 472 (1982) (explaining that standing applies to "the party who invokes the court's authority"); 13A WRIGHT \& MILLER, supra note 83, § 3531, at 4-6. But see Arizonans for Official English v. Arizona, 520 U.S. 43, 64 (1997) ("Standing to sue or defend is an aspect of the case-orcontroversy requirement." (emphasis added)).

88. Flynt v. Lombardi, 782 F.3d 963 (8th Cir. 2015).

89. Id. at 967 .

90. Id.

91. Mausolf v. Babbitt, 85 F.3d 1295, 1300 (8th Cir. 1996). 
between Rule 24(a)(2) and Rule 24(b) intervenors vis-à-vis Article III. ${ }^{92}$

The larger issue with the Eighth Circuit's position in Mausolf is that it effectively writes Rule 24(b) out of the Federal Rules of Civil Procedure. Rule 24(b) allows permissive intervention if the party "has a claim or defense that shares with the main action a common question of law or fact." ${ }^{93}$ If, as these courts believe, Rule 24(a)(2)'s interest requirement does not satisfy Article III, then Rule 24(b), which exists to accommodate parties whose interest is not sufficient under Rule 24(a)(2), ${ }^{94}$ is without any meaning. How could a party's interest be sufficient to satisfy Article III yet insufficient to qualify for intervention under Rule 24(a)(2)? ${ }^{95}$ Requiring Article III standing of Rule 24(b) intervenors leaves the Rule without any conceivable application.

2. The "Floodgates" Concern. Another oft-cited rationale for the minority position is that allowing intervention without Article III standing would permit "any organization or individual with only a philosophic identification with a defendant-or a concern with a possible unfavorable precedent ... to intervene and influence the

92. A similar problem confronts the Eighth Circuit's treatment of Rule 19 of the Federal Rules of Civil Procedure, which requires that a party be joined to existing litigation if "that person claims an interest relating to the subject of the action and is so situated that disposing of the action in the person's absence may ... impair or impede the person's ability to protect the interest." FED. R. CIV. P. 19(a)(1)(B)-(B)(i). Rule 19's language is almost identical to that of Rule 24, and, according to the Eighth Circuit, the consequences of joining a party under Rule 19 who lacks standing should be the same as doing so under Rule 24. Yet in applying Rule 19, the Eighth Circuit does not inquire into the joined party's standing. See, e.g., Two Shields v. Wilkinson, 790 F.3d 791, 798 (8th Cir. 2015) (omitting standing as a factor relevant to Rule 19 analysis); see also Karastelev, supra note 21 , at 470 (noting the Rule 19 issue).

93. FED. R. CIV. P. 24(b)(1)(B).

94. See 7C Wright \& MiLLER, supra note 31, § 1911, at 450-68 (explaining that Rule 24(b) exists to allow intervention where Rule 24(a)(2) would not); see also SEC v. U.S. Realty \& Improvement Co., 310 U.S. 434, 459 (1940) ("[Rule 24(b)] plainly dispenses with any requirement that the intervenor shall have a direct personal or pecuniary interest in the subject of the litigation.").

95. For example, let's say our plaintiff from Lujan wants to intervene in an ongoing ESA suit, and her claims share a question of law or fact with the plaintiff's claims. Suppose, though, that her interest in the particular endangered species is not strong enough to satisfy Rule 24(a)(2), meaning that it is also not strong enough to satisfy Article III standing (as she cannot have an injury without at least a strong interest). Will her Rule 24(b) motion succeed if she is required to satisfy Article III standing? No: she will fail because, given that she didn't have an interest sufficient for a Rule 24(a)(2) motion, she will not be able to satisfy Article III standing a fortiori. 
course of litigation." ${ }^{96}$ As articulated by the Eighth Circuit, the fear is that courts will be turned into "judicial versions of college debating forums." ${ }^{97}$ The circuits' concern with misuse of judicial resources is laudable, but the fear is misplaced.

First, it is doubtful as an empirical matter that the minority circuits' fear-that removing Article III standing from Rule 24 intervention will open the floodgates to any merely interested partyhas come to pass in the majority of circuits allowing intervention without standing. ${ }^{98}$ Second, Rule 24(a)(2) contains three limiting criteria, all of which the prospective intervenor must meet. ${ }^{99}$ It is unlikely that someone with a merely "philosophic identification" with a given defendant would have a sufficient interest under Rule 24(a)(2) or be able to show how an adverse ruling would "impair or impede" her ability to protect the interest.

Even if this is fear were well founded, Article III standing would be the wrong way to address it. Recall that the Supreme Court in Lexmark clarified that standing is strictly a matter of jurisdiction, not prudence, by reiterating the "virtually unflagging" requirement that "'a federal court[] . . hear and decide' cases within its jurisdiction."100 In the wake of Lexmark, the D.C. Circuit in Crossroads Grassroots Policy Strategies v. FEC ${ }^{101}$ discontinued its application of the zone-ofinterest test-a prudential rather than Article III standing requirement-to Rule 24 intervenors. ${ }^{102}$ Despite proclaiming in Crossroads that "there is no need for another layer of judge-made

96. Deutsche Bank Nat'l Tr. Co. v. FDIC, 717 F.3d 189, 195 (D.C. Cir. 2013) (Silberman, J., concurring).

97. Mausolf v. Babbitt, 85 F.3d 1295, 1301 (8th Cir. 1996) (quoting Valley Forge Christian Coll. v. Ams. United for Separation of Church \& State, Inc., 454 U.S. 464, 473 (1982)).

98. Though an imperfect proxy, the time period from filing date to final trial disposition is longest in district courts of the Seventh Circuit (12.6 months), which applies Article III to intervenors, and shortest in district courts of the Eleventh Circuit ( 8.48 months), which allows intervenors without regard to standing. See U.S. COURTS, FEDERAL COURT MANAGEMENT STATISTICS - COMPARISON WITHIN CIRCUIT - DURING THE 12-MONTH PERIOD ENDING JUNE 30, 2016 (June 30, 2016), http://www.uscourts.gov/sites/default/files/data_tables/fcms_na_dist comparison0630.2016.pdf [https://perma.cc/2XNT-PFUL].

99. See 7C WRIGHT \& MilleR, supra note 31, § 1908, at 295 ("As amended in 1966, Rule 24(a)(2) creates a threefold test for intervention of right....”); see FED. R. CIV. P. 24(a)(2) (requiring that intervenors under 24(a)(2) demonstrate a protectable interest that may be impaired unless the intervenor is allowed to defend it).

100. Lexmark Int'l, Inc. v. Static Control Components, Inc., 134 S. Ct. 1377, 1386 (2014) (quoting Sprint Commc'ns, Inc. v. Jacobs, 134 S. Ct. 584, 591 (2013)).

101. Crossroads Grassroots Policy Strategies v. FEC, 788 F.3d 312 (D.C. Cir, 2015).

102. Id. at 319. 
prudential considerations to deny intervention," 103 the court cited approvingly to a concurrence advocating for the prudential use of Article III standing in Rule 24 cases. ${ }^{104}$ In so doing, the D.C. Circuit did not technically violate Lexmark insofar as it did not resurrect the prudential standing limitations Lexmark interred. However, by appealing to a prudential (as opposed to jurisdictional) motivation for invoking Article III standing, the D.C. Circuit violated the idea behind Lexmark - that Article III standing is meant only to define jurisdiction.

3. The "Equal Footing" Rationale. The final rationale underlying the minority position is that if an "intervenor seeks to participate on an equal footing with the original parties to the suit, he must satisfy the standing requirements imposed on those parties." ${ }^{105}$ Because "an intervenor may be seeking relief different from that sought by and of the original parties ... [which] may make it really a new case," 106 and because no case can be sustained without Article III standing, the potentially case-shifting intervenor must have standing. This is a fair concern, as Rule 24 intervenors are presumptively ${ }^{107}$ given full-party status, allowing them to participate in practically all aspects of the trial. ${ }^{108}$ If an intervenor so changes the focus of a case such that it no longer centers on the original plaintiff's claims, the adjudicating court may no longer have jurisdiction.

But this position overlooks two important points. First, many parties who seek to intervene do so only to present different arguments or evidence, not to request different relief. ${ }^{109}$ In these cases, intervention functions in a similar way to an amicus brief, but with

103. Id. at 320 (emphasis added).

104. Id. The case to which the court referred was Deutsche Bank Nat'l Tr. Co. v. FDIC, 717 F.3d 189 (D.C. Cir. 2013), in which Judge Silberman explained that "[the D.C. Circuit's] rule requiring all intervenors to demonstrate Article III standing prudently guards against [undue intervention by third parties]." Id. at 195.

105. City of Cleveland v. Nuclear Regulatory Comm'n, 17 F.3d 1515, 1517 (D.C. Cir. 1994).

106. City of Chicago v. FEMA, 660 F.3d 980, 985 (7th Cir. 2011).

107. However, for a discussion of courts' authority to limit intervenors' powers under Rule 24(a)(2), see infra notes 112-113.

108. See, e.g., Smith v. Marsh, 194 F.3d 1045, 1051 (9th Cir. 1999) ("[A]s a general rule, intervenors are permitted to litigate fully once admitted to a suit." (alteration in original) (quoting League of United Latin Am. Citizens v. Wilson, 131 F.3d 1297, 1304 (9th Cir. 1997))).

109. See, e.g., Grutter v. Bollinger, 188 F.3d 394, 400 (6th Cir. 1999) (explaining that the intervenor sought to make arguments that "institutional pressures" prevented the original party from making). 
important differences. ${ }^{110}$ Some parties intervene for much more limited purposes, which may entail virtually no participation in the litigation. ${ }^{111}$ Second, this position overlooks the authority Rule 24 gives courts to limit the participation of intervening parties. To be sure, the text of Rule 24 confers no such power, but the Advisory Committee's note to the 1966 amendment grants courts broad, discretionary power to condition intervenors' activities. ${ }^{112}$ This power is widely recognized ${ }^{113}$ and compares favorably with Article III standing as a means of limiting intervenor participation. Whereas Article III categorically rejects a class of intervenors who might contribute valuably to the resolution of a case, imposing limits under Rule 24 allows judges to take advantage of the perspective and information offered by intervenors while avoiding potential procedural complications.

110. For a consideration of why intervention is superior to an amicus brief for most parties, see infra Part III.B.1.

111. For instance, some parties intervene to obtain information they can access only as a party. See, e.g., Flynt v. Lombardi, 782 F.3d 963, 967 (8th Cir. 2015) (permitting a party to intervene who only sought to modify a protective order); Haworth v. Steelcase, Inc., 12 F.3d 1090, 1092 (Fed. Cir. 1993) (affirming the lower court's refusal to allow a party to intervene who was seeking discovery relevant to a parallel litigation with one of the original parties). Other parties seek to intervene as neutral participants in settlement negotiations. See, e.g., United States v. Metro. St. Louis Sewer Dist., 569 F.3d 829, 833 (8th Cir. 2009) (refusing to permit the intervention of a Missouri trade association in settlement negotiations between the United States, Missouri, and the Metropolitan St. Louis Sewer District for violations of the Clean Water Act).

112. See FED. R. CIV. P. 24(a)(2) advisory committee's note to the 1966 amendment ("An intervention of right under the amended rule may be subject to appropriate conditions or restrictions responsive among other things to the requirements of efficient conduct of the proceedings."). Courts often will limit the intervenor's ability to raise new claims. See, e.g., Brady Campaign to Prevent Gun Violence v. Salazar, 612 F. Supp. 2d 1, 11 n.8 (D.D.C. 2009) (allowing parties to intervene "subject to limitations prohibiting them from raising claims outside the scope of those raised by the original parties or from raising collateral issues"). Courts also frequently limit the intervenor's discovery. See, e.g., United States v. Duke Energy Corp., 171 F. Supp. 2d 560, 565-66 (M.D.N.C. 2001) (limiting intervenors' "ability to initiate unilateral independent discovery without leave of the court").

113. See, e.g., Trbovich v. United Mine Workers of Am., 404 U.S. 528, 528 (1972) (remanding to "allow limited intervention" under Rule 24); Forest Cty. Potawatomi Cmty. v. United States, 317 F.R.D. 6, 15 (D.C. Cir. 2016) ("[I]t is now a firmly established principle that reasonable conditions may be imposed even upon one who intervenes as of right." (alteration in original) (quoting Beauregard, Inc. v. Sword Servs. L.L.C., 107 F.3d 351, 352-53 (5th Cir. 1997))); United States v. Albert Inv. Co., 585 F.3d 1386, 1396 (10th Cir. 2009) (same); Dacotah Chapter of Sierra Club v. Salazar, No. 1:12-cv-065, 2012 WL 3686742, at *2 (D.N.D. Aug. 27, 2012) (same); Florida Med. Ass'n, Inc. v. Dep't of Health, Educ. \& Welfare, No. 3:78-cv-178-J-34MCR, 2011 WL 4459387, at *11 n.13 (M.D. Fla. Sept. 26, 2011) (same); United States v. Arch Coal, Inc., No. 2:110133, 2011 WL 2493072, at*12 (S.D. W. Va. June 22, 2011) (same); TiVo Inc. v. AT \& T Inc., No. 2:09-CV-259, 2010 WL 10922068, at*4 (E.D. Tex. Mar. 31, 2010) (same). 


\section{The Supreme Court's Sub Silentio Treatment}

The Supreme Court has expressly declined to resolve whether Rule 24(a)(2) intervention requires Article III standing when the movant does not seek different relief. ${ }^{114}$ Though the Court has not supplied a definitive answer, it has "sub silentio" endorsed the majority position. ${ }^{115}$ In Diamond v. Charles,${ }^{116}$ the Court ruled that when the original party declines to appeal a judgment, an intervenor must demonstrate separate Article III standing to appeal. ${ }^{117}$ This makes perfect sense: the original plaintiff in Diamond, the State of Illinois, dropped out of the litigation after the court of appeals' decision, taking with it the original case or controversy and, a fortiori, the Supreme Court's Article III jurisdiction. ${ }^{118}$ But "[h]ad the State sought review ... Diamond, as an intervening defendant below, also would be entitled to seek review, enabling him to file a brief on the merits, and to seek leave to argue orally." "119 That is, Diamond would have been treated as a full party, but his "ability to ride 'piggyback' on the State's undoubted standing exist[ed] only if the State [had] in fact [been] an appellant before the Court." 120 Though the Court in Diamond declined to define the general relationship between Article III and Rule 24(a)(2), the Court's dictum suggests that standing-less intervenors are able to "piggyback" on the standing of the original plaintiff. ${ }^{121}$

Since Diamond, the Supreme Court has given more authority to Diamond's dictum, albeit obliquely. In McConnell v. FEC ${ }^{122}$ the Court considered a challenge to sections of the Bipartisan Campaign Reform Act defended by the FEC and numerous defendant-intervenors.

114. See Diamond v. Charles, 476 U.S. 54, 68-69 (1986) ("We need not decide today whether a party seeking to intervene before a district court must satisfy not only the requirements of Rule 24(a)(2), but also the requirements of Art. III.").

115. Laroe Estates, Inc. v. Town of Chester, 828 F.3d 60, 65 (2d Cir. 2016) ("[I]t is fair to say that while the Supreme Court has not explicitly endorsed our approach, it has sub silentio permitted parties to intervene in cases that satisfy the "case or controversy' requirement without determining whether those parties independently have standing.”), vacated, $137 \mathrm{~S}$. Ct. 1645 (2017).

116. Diamond v. Charles, 476 U.S. 54 (1986).

117. Id. at 68 .

118. Id. at 63-64.

119. Id. at 64 .

120. Id.

121. Id.

122. McConnell v. FEC, 540 U.S. 93 (2003), overruled on other grounds by Citizens United v. FEC, 558 U.S. 310 (2010). 
Though one plaintiff raised the issue of intervenor standing, ${ }^{123}$ the Court ultimately ruled on the merits of the suit without determining that the defendant-intervenors had standing. ${ }^{124}$ As the Court explained, because "the Federal Elections Commission (FEC) has standing ... we need not address the standing of the intervenor-defendants, whose position here is identical to the FEC's." 125 In other words, the Court considered the defendant-intervenors' standing irrelevant because they had made substantially the same arguments as the FEC, which did have standing.

Though this sentence sounds like a bit of forgettable throat clearing, it is significant given McConnell's procedural posture. Whereas Diamond was a case about Article III jurisdiction, McConnell was decided on the merits. Accordingly, McConnell had to have presented a justiciable case or controversy or else the Court would not have had jurisdiction to rule on the merits. ${ }^{126}$ But if the minority's, particularly the Eighth Circuit's, interpretation is correct, the Court could not have decided the case on the merits without first finding that all of the many defendant-intervenors had standing. Were even one of them to lack standing, the case would not be justiciable. That McConnell was decided on the merits, therefore, casts substantial doubt on the proposition that "an Article III case or controversy, once joined by intervenors who lack standing, is - put bluntly - no longer an Article III case or controversy." "127

The Court's dictum in Diamond and its ruling in McConnell strongly suggest that Rule 24 intervenors need not have Article III standing. At the very least, these decisions critically undermine the hard-line position taken by the Eighth Circuit in Mausolf. More

123. Id. at 233.

124. Id.

125. Id.

126. See Steel Co. v. Citizens for a Better Env't, 523 U.S. 83, 94 (1998) (rejecting "hypothetical jurisdiction" because "it carries the courts beyond the bounds of authorized judicial action and thus offends fundamental principles of separation of powers"); Friends of Earth, Inc. v. Laidlaw Envtl. Servs. (TOC), Inc., 528 U.S. 167, 180 (1984) (noting that the Supreme Court has "an obligation to assure [itself] that [plaintiffs have] Article III standing at the outset of the litigation"); Marbury v. Madison, 5 U.S. (1 Cranch) 137, 138 (1803) (declining to issue a writ of mandamus because the applicable statute could not confer original jurisdiction).

127. Mausolf v. Babbitt, 85 F.3d 1295, 1300 (8th Cir. 1996). Minority circuits have not addressed the discrepancy between their position and the Supreme Court's one-plaintiff rule whereby the Supreme Court proceeds to the merits of a case without determining that all plaintiffs have standing. For an analysis of the one-plaintiff rule and its use by federal courts, see generally Aaron-Andrew P. Bruhl, One Good Plaintiff Is Not Enough, 67 DUKE L.J. (forthcoming Dec. 2017). 
broadly, these decisions call into question the validity of applying Article III to Rule 24 intervenors at all. If the inclusion of an intervenor without standing does not destroy Article III jurisdiction, and if Article III is a jurisdictional limitation rather than a filtering mechanism, it is unclear how one could justify excluding intervenors without appealing to prudential concerns alone. Ultimately, if only prudential concerns justify application of Article III to intervenors, the minority position is all the more dubious after Lexmark.

\section{Rule 24 AND the Two Process CONCERnS OF StARE DeCISIS}

As Part I demonstrates, there is no conclusive answer to the question of whether Rule 24 requires that intervenors demonstrate Article III standing. Given this stalemate, the rest of this Note argues that two considerations-due process and the process of judicial decisionmaking - cut in favor of allowing parties to intervene without demonstrating standing. Because stare decisis requires courts to follow precedent, it is important that cases be decided correctly-that is, by taking into account the manifold ways a decision will affect future litigants - in the first instance.

\section{A. The Scope of Strength of Stare Decisis}

It was once a widely held view that "judicial opinions were of little import." ${ }^{128}$ Principles of vertical and horizontal stare decisis required courts to follow the holdings of their superior (and sometimes coordinate) courts, but the opinions were virtually without force. ${ }^{129}$ This argument still has its proponents, and there are a number of ways in which this position is formally correct. ${ }^{130}$ But as anyone who has written a case brief can attest, those in the legal field-particularly attorneys-place substantial importance on the rationales of legal decisions, not just their holdings. This attention to legal opinions, as opposed to holdings alone, is well founded as courts often treat their opinions as if they set general rules for society that affect parties beyond the scope of the instant case. ${ }^{131}$ That this occurs is not exactly a

128. Michael Abramowicz \& Thomas B. Colby, Notice-and-Comment Judicial Decisionmaking, 76 U. CHI. L. REV. 965, 974 (2009).

129. Id.

130. Id. at $975 \&$ n. 45 .

131. See Frank H. Easterbrook, The Supreme Court 1983 Term-Foreword: The Court and the Economic System, 98 HARV. L. REV. 4, 5-8 (1984) ("Today cases often are just excuses for the creation or alteration of [societal] rules."). 
secret. ${ }^{132}$ Though the precedential weight we give to opinions reflects a fairness-driven preference for "treating like cases alike," 133 it is also a functional requirement of our system. As the Ninth Circuit put it:

The Supreme Court cannot limit its constitutional adjudication to the narrow facts before it in a particular case. In the decision of individual cases the Court must and regularly does establish guidelines to govern a variety of situations related to that presented in the immediate case. The system could not function if lower courts were free to disregard such guidelines whenever they did not precisely match the facts of the case in which the guidelines were announced. ${ }^{134}$

It is thus not surprising that people at all levels of the legal professionstudents, professors, lawyers, and judges-pay close attention to judicial opinions.

What is perhaps surprising is the preclusive effect courts give to opinions. It would be one thing if, as the Ninth Circuit describes, the broad reach of judicial opinions established flexible "guidelines" judges could apply with some discretion. In practice, however, judicial opinions are more binding than guiding. Once a judicial opinion is issued by an appellate court on a given matter of law, that interpretation will, absent extraordinary circumstances, ${ }^{135}$ govern future cases within the same jurisdiction regardless of the arguments future parties may advance against it. ${ }^{136}$ Horizontal stare decisis, which requires courts to follow their coordinate courts' decisions, functions primarily at the appellate level ${ }^{137}$ where doctrinal rules require judges

132. See, e.g., Cty. of Allegheny v. ACLU, 492 U.S. 573, 668 (1989) (Kennedy, J., concurring) ("As a general rule, the principle of stare decisis directs us to adhere not only to the holdings of our prior cases, but also to their explications of the governing rules of law."); Richmond Newspapers, Inc. v. Virginia, 448 U.S. 555, 595 (1980) (Brennan, J., concurring) ("While individual cases turn upon the controversies between parties, or involve particular prosecutions, court rulings impose official and practical consequences upon members of society at large.").

133. H.L.A. Hart, Positivism and the Separation of Law and Morals, 71 HARV. L. REV. 593, 624 (1958).

134. United States v. Underwood, 717 F.2d 482, 486 (9th Cir. 1983).

135. For a discussion of stare decisis and the grounds on which federal courts may overrule precedent, see infra notes 139-154 and accompanying text.

136. The exception to this rule is Rule 11, which allows a party to make "a nonfrivolous argument for extending, modifying, or reversing existing law or for establishing new law." FED. R. CIV. P. 11(b)(2). For reasons discussed below, there is substantial risk in making this type of Rule 11 argument. For an explanation of the circumstances under which Rule 11 sanctions are levied, see infra note 177 and accompanying text.

137. Horizontal stare decisis is significantly less important at the district level, and sometimes completely unimportant. Courts in at most one district are required to follow intra-circuit precedent. See Kerr v. Hurd, 694 F. Supp. 2d 817, 843 (S. D. Ohio 2010) ("In the absence of 
to follow the decision of a previous panel unless a subsequent en banc or Supreme Court decision overrules it. ${ }^{138}$ For example, if the Ninth Circuit holds in Litigant A's case that "no vehicles in the park" means literally no vehicles, Litigant B effectively cannot argue that the rule should apply only to certain types of vehicles. Horizontal stare decisis prevents any panel within the circuit from ruling contrary to a previous panel's decision. Litigant B's only recourse is to obtain en banc or Supreme Court review. But mere error correction is almost certainly not going to get him there. En banc review is granted only when a case presents a "question of exceptional importance" or one on which panels within the circuit have disagreed. ${ }^{139}$ Similarly, the Supreme Court grants petitions for certiorari only when a case presents an issue of national importance or is one on which the circuit courts have split. ${ }^{140}$ As a result, "[f]irst-in-time litigants usually receive the only opportunity to air arguments on the merits of a legal issue." 141

Assume, perhaps, that the Ninth Circuit or Supreme Court is eager to revisit the interpretation of "no vehicles in the park," and so agrees to hear Litigant B's case. Even in this improbable scenario, stare decisis further prevents courts from overruling themselves absent special circumstances. As the Supreme Court explained in Planned

supervening case authority from the Supreme Court or the Court of Appeals, this Court is bound, under the doctrine of stare decisis, to follow decisions of its own judges."). But see Michael R. Mertz, Comment to Eugene Volokh, District Court Opinions Precedential Within the Same District?, VOLOKH CONSPIRACY (May 25, 2010, 8:33 PM), http://volokh.com/2010/05/25/districtcourt-opinions-precedential-within-the-same-district [https://perma.cc/FN8S-AJ49] (providing comment of Magistrate Judge Michael Merz, author of the opinion in Kerr v. Hurd, acknowledging that "[t]he comments [on the Volokh Conspiracy] persuade me the quoted statement from my opinion is wrong"). In other jurisdictions, there is a presumption in favor of following intra-district precedent. See United States v. Hirschorn, 21 F.2d 758, 759 (S.D.N.Y. 1927) (explaining that "the general rule [is] that a matter which is decided by any District Judge in this district should be, as a matter of comity, without re-examination by another judge, so decided"). In general, "federal district court decisions are treated like unpublished appellate decisions: they may be disregarded in future cases except for the purposes of res judicata and collateral estoppel." Thomas R. Lee \& Lance S. Lehnhof, The Anastasoff Case and the Judicial Power to "Unpublish" Opinions, 77 NOTRE DAME L. REV. 135, 168 (2001).

138. See Amy Coney Barrett, Stare Decisis and Due Process, 74 U. Colo. L. REV. 1011, 1018 n.20 (2003) (noting that every circuit follows the rule that one panel cannot override another).

139. FED. R. APP. P. 35(a); see also EEOC v. Ind. Bell Tel. Co., 256 F.3d 516, 529 (7th Cir. 2001) (en banc) (Posner, J., concurring) ("We take cases en banc... not just to review a panel opinion for error ...."). The rule that no panel can overrule another is not grounded in statute and is sometimes ignored. See generally Phillip M. Kannan, The Precedential Force of Panel Law, 76 MARQUETTE L. REV. 755 (1993) (analyzing the origins and application of the interpanel rule).

140. SUP. CT. R. 10.

141. Barrett, supra note 138 , at 1017. 
Parenthood of Southeastern Pennsylvania v. Casey, ${ }^{142}$ the presumption of stare decisis in the federal judiciary ${ }^{143}$ is so strong that precedent cannot be overruled unless a series of factors weighs against it. To be overruled, precedent should be "unworkable"144 and should be discredited by subsequent factual ${ }^{145}$ and legal ${ }^{146}$ developments. It should also not have engendered "reliance," 147 - in a more general than legal sense $\mathrm{e}^{148}$-and the overruling should not appear to be so ideologically motivated as to tarnish the court's reputation. ${ }^{149}$ The Court in Casey identified only two precedents, Lochner v. New York ${ }^{150}$ and Plessy v. Ferguson, ${ }^{151}$ that ticked all of the boxes. ${ }^{152}$ To be clear, precedents have been overruled even when they have not met one or more of the conditions enumerated in Casey, ${ }^{153}$ but there is a strong presumption in federal courts against overruling precedent. ${ }^{154}$

142. Planned Parenthood of Se. Pa. v. Casey, 505 U.S. 833 (1992).

143. Barrett, supra note 138, at 1018-19 (noting that "[n]either the Supreme Court nor any of the courts of appeals will overrule precedent absent 'special justification,"” which includes an examination of the Casey factors).

144. Casey, 505 U.S. at 855.

145. Id. at 860 .

146. Id. at 857 .

147. Id. at $855-56$.

148. As one commentator has explained:

While many people may have strong ideological or personal stakes in the [legality of abortion] being decided one way or another, there is relatively little "reliance" in the sense of the existing rule having tended to create its own reliance-having caused people to "sink costs," so to speak. There is, for example, less investment-backed social expectation in a particular legal regime concerning abortion than there was for continuation of "separate but equal" under Plessy v. Ferguson.

Michael Stokes Paulsen, Abrogating Stare Decisis by Statute: May Congress Remove the Precedential Effect of Roe and Casey?, 109 YALE L.J. 1535, 1554-55 (2000).

149. Casey, 505 U.S. at 861, 865-66.

150. Lochner v. New York, 198 U.S. 45 (1905).

151. Plessy v. Ferguson, 163 U.S. 537 (1896).

152. Casey, 505 U.S. at 861-63.

153. See, e.g., Leegin Creative Leather Prods., Inc. v. PSKS, Inc., 551 U.S. 877, 906 (2007) (noting that "[r]eliance interests do not require us to reaffirm [an incorrect precedent]"); Garcia v. San Antonio Metro. Transit Auth., 469 U.S. 528, 558 (1985) (Powell, J., dissenting) (criticizing the majority for overruling what "[l]ess than three years ago ... in [a] unanimous decision" had been considered "settled constitutional doctrine").

154. This presumption is even stronger in certain contexts. For example, when a court interprets a federal statute and Congress fails to amend it, the lack of amendment is seen as approval of the court's interpretation. See, e.g., Hohn v. United States, 524 U.S. 236,251 (1998) ("Considerations of stare decisis have special force in the area of statutory interpretation, for here, unlike in the context of constitutional interpretation, the legislative power is implicated, and Congress remains free to alter what we have done." (quoting Patterson v. McLean Credit Union, 491 U.S. 164, 172-73 (1989))). 


\section{B. Stare Decisis's Process Problems}

The strength of stare decisis in the federal judiciary implicates two separate processes. The first is procedural due process, which is undermined by stare decisis as practiced in the federal judiciary. The second is the judicial decisionmaking process, which is complicated by the epistemic constraints of case-based rulemaking and the adversarial presentation of evidence in our legal system. These two process concerns are considered below in turn.

1. Due Process. The Constitution twice guarantees that the government will not deprive anyone of "life, liberty, or property without due process of law." 155 In the context of judicial proceedings and other types of individualized adjudications, due process includes the right to be heard on the merit of one's claims and defenses. ${ }^{156} \mathrm{By}$ effectively foreclosing the litigation of certain issues decided in previous cases, stare decisis is in tension with this right: in a significant sense, stare decisis limits the ability to be heard in anything more than a literal sense on one's claims and defenses. For instance, a defendant who wants to argue that the employees of her riverboat casino are not "seamen" for the purposes of the Fair Labor Standards Act is effectively barred in the Seventh Circuit from doing so, whether or not her arguments were heard in the precedent-setting case or the case was even decidedly correctly. ${ }^{157}$

Federal courts have rarely addressed the tension between stare decisis and due process. When they have, their reasoning has been more obscuring than illuminating. In Colby v. J.C. Penney Co. ${ }^{158}$ the Seventh Circuit reversed a district judge for treating the precedent of another district court as outcome determinative in a sex discrimination suit. ${ }^{159}$ Because "the parties to cases before us are entitled to [the judge's] independent judgment," the district court erred by treating the precedent as binding rather than persuasive. ${ }^{160}$ Similarly, in Northwest

155. U.S. CONST. amends. V, XIV.

156. See, e.g., Richards v. Jefferson Cty., 517 U.S. 793,797 n.4 (1996) ("The opportunity to be heard is an essential requisite of due process of law in judicial proceedings.").

157. See Tate v. Showboat Marina Casino P'ship, 431 F.3d 580, 582-83 (7th Cir. 2005) ("The doctrine of stare decisis 'imparts authority to a decision, depending on the court that rendered it, merely by virtue of the authority of the rendering court and independently of the quality of its reasoning."' (quoting Midlock v. Apple Vacations W., Inc., 406 F.3d 453, 457 (7th Cir. 2005))).

158. Colby v. J.C. Penney Co., 811 F.2d 1119 (7th Cir. 1987).

159. Id. at 1128 .

160. Id. at 1123 . 
Forest Resource Council v. Dombeck ${ }^{161}$ the D.C. Circuit reversed its district court for treating out-of-circuit district court precedent as binding in a challenge to an environmental plan. ${ }^{162}$ Because the district court was not compelled to follow another circuit, the district court had "deprive[d] appellants of their right to be heard on the merits of their claims." "163 Although these decisions pay some attention to the preclusive effects of stare decisis, it is unclear what they stand for. As one commentator has noted, "Dombeck and Colby raise more questions than they answer." 164 Both the Seventh and D.C. Circuits in these cases flagged the potential due process concerns underlying the issue-preclusive effects of stare decisis. By highlighting the nonbinding nature of other-circuit and other-district precedent, however, the courts imply that analogous precedent from an appropriate source would not present the same due process concern. ${ }^{165}$ The salience of this distinction is less than clear. Precluding consideration of certain issues because of stare decisis burdens the right to be heard regardless of the precedent's source; whatever the precedent's pedigree, the instant litigant is effectively precluded by the resolution of someone else's case from making a claim in hers.

This blind spot likely owes to the traditional understanding of stare decisis. ${ }^{166}$ In the common law, stare decisis was considered a doctrine that applied to judges rather than parties. In justifying the life tenure of federal judges, Alexander Hamilton explained:

To avoid an arbitrary discretion in the courts, it is indispensable that they should be bound down by strict rules and precedents, which serve to define and point out their duty in every particular case that comes before them; and it will readily be conceived from the variety of controversies which grow out of the folly and wickedness of mankind, that the records of those precedents must unavoidably swell to a very considerable bulk, and must demand long and laborious study to acquire a competent knowledge of them. ${ }^{167}$

161. Nw. Forest Res. Council v. Dombeck, 107 F.3d 897 (D.C. Cir. 1997).

162. Id. at 901 .

163. Id. at 898 .

164. Barrett, supra note 138 , at 1027.

165. Id.

166. See id. at 1031 ("To the extent that the traditional account [of stare decisis] has focused on precedent's binding effect, it has focused on judges.").

167. THE FedERAlist No. 78, at 407 (Alexander Hamilton) (Gideon ed., 2001) (emphasis added). 
In a similar but more recent vein, the Federal Circuit has described stare decisis as "a doctrine that binds courts" but "does not bind parties." 168 Though that might be true in a formal sense, stare decisis inevitably affects future parties by binding judges to follow prior decisions: a judge who is commanded by stare decisis to follow a previous court's interpretation of "all vehicles" is a judge whose litigants effectively cannot contest that interpretation.

The judicial treatment of stare decisis is even more questionable when one compares it to the doctrine of issue preclusion. ${ }^{169}$ Like stare decisis, issue preclusion promotes judicial efficiency and consistency by binding litigants to prior judgments of the same issue. ${ }^{170}$ Unlike stare decisis, however, issue preclusion bars a party from litigating a certain issue only if the party had a "full and fair opportunity"171 to do so previously. In contemporary doctrine, parties can be precluded from litigating an issue only if they were a party in previous litigation in which the issue was resolved, or if they were in privity with such a party. The doctrinal treatment of stare decisis, on the other hand, evinces no such concern for due process. Stare decisis assumes a prior resolution of a particular issue binds future parties, even if those parties had no hand in the precedent-setting litigation and thus had no opportunity to be heard. ${ }^{172}$

The traditional explanation for why issue preclusion and stare decisis treat parties differently is the putative flexibility of stare decisis. ${ }^{173}$ Issue preclusion is rigid-once an issue is settled, it is settled

168. Nat'l Org. of Veterans' Advocates, Inc. v. Sec'y of Veterans Affairs, 260 F.3d 1365, 137374 (Fed. Cir. 2001).

169. See Barrett, supra note 138, at 1032-43 (comparing the judicial treatment of stare decisis to that of res judicata).

170. See Parklane Hosiery Co. v. Shore, 439 U.S. 322, 329-30 (1979) (explaining that defensive issue preclusion is meant to deny litigants the ability to relitigate issues by "merely 'switching adversaries"” (quoting Bernhard v. Bank of Am. Nat. Tr. \& Sav. Ass'n., 19 Cal. 2d 807, 813 (1942))).

171. Id. at 328 .

172. See Bethesda Lutheran Homes \& Servs., Inc. v. Born, 238 F.3d 853, 858 (7th Cir. 2001) ("[S]tare decisis ... bars a different party from obtaining the overruling of a decision. The existence of different parties is assumed by the doctrine, rather than being something that takes a case outside its reach.").

173. See id. ("Of course, stare decisis is a less rigid doctrine than res judicata. But it is not a noodle."); RESTATEMENT (SECOND) OF JUDGMENTS $§ 29$ cmt. i (AM. LAW INST. 1982) ("When the issue involved is one of law, stability of decision can be regulated by the rule of issue preclusion or by the more flexible rule of stare decisis."); Barrett, supra note 138, at 1043-47 (suggesting "the supposed flexibility of stare decisis" as the reason "the doctrines [of issue preclusion and stare decisis] treat nonparties differently"). 
for the purposes of all litigation involving the same parties or privies. Stare decisis, on the other hand, is considered to be more flexible inasmuch as parties can distinguish their cases from precedent, appeal an unfavorable decision, or make nonfrivolous arguments that a precedent should be overruled. As intuitive as this seems, the distinction is greater in theory than in practice. There is a limit on the ability of courts to distinguish one case from another. ${ }^{174}$ And the ability to distinguish does not make stare decisis any more flexible: the act of distinguishing a case is one of arguing why the instant facts are materially different from those of a precedential case. The act of distinguishing assumes stare decisis binds but argues that the instant case is not within the scope of the binding precedent.

At the appellate level, the ability to appeal turns entirely on the authority of the precedent-for example, appealing a district versus appellate court decision-and whether the appealed issue is sufficiently important to merit (re-)consideration in the context of en banc and Supreme Court appeals. ${ }^{175}$ If the authority is sufficiently great, or the urged basis of appeal is mere error correction, one is unlikely to obtain review. Though Rule 11(b)(2) does allow one to make nonfrivolous arguments for the reversal of precedent, ${ }^{176}$ the same Rule 11 mandates sanctions for arguments that are not "reasonable,"177 thereby deterring challenges to precedent. Moreover, because Rule 11(b)(2) challenges ask judges to render a decision despite the weight of precedent, such challenges are often likely to fail. Consequently, an attorney facing pressure from clients to reduce litigation costs is likely to stay away from Rule 11 arguments that, even when well made, are unlikely to persuade.

Under current doctrine, stare decisis and issue preclusion similarly preclude parties from relitigating issues once decided, yet due process limits only issue preclusion. But perhaps this is the wrong way to think

174. See Barrett, supra note 138, at 1021 (“A court's capacity for 'honest' distinguishing ... does somewhat blunt a case's effect on later litigants. Court cannot, however, fairly distinguish every case.").

175. For an examination of stare decisis in the federal judiciary, see supra Part II.A.

176. See FED. R. CIV. P. 11(b)(2) (allowing parties to make "a nonfrivolous argument for extending, modifying, or reversing existing law or for establishing new law").

177. See Corroon v. Reeve, 258 F.3d 86, 92 (2d Cir. 2001) ("Rule 11 is violated when it is clear under existing precedents that a pleading has no chance of success and there is no reasonable argument to extend, modify, or reverse the law as it stands."). But see McKnight v. Gen. Motors Corp., 511 U.S. 659, 660 (1994) (per curiam) (providing that an argument is not frivolous if, though "foreclosed by Circuit precedent," it concerns an issue that has "divided the District Courts and its answer [is] not so clear as to make [the] position frivolous"). 
of it. Maybe the explanation for courts' reluctance to apply due process to stare decisis has less to do with the effects of the two doctrines than with the relationship between precedent-setting courts and future litigants. As one commentator has noted, Colby and Dombeck could stand for the proposition that the Due Process Clause guarantees a full hearing on the merits of one's arguments only in matters of first impression. ${ }^{178}$ Under this theory, a precedent-setting court would sit as adjudicator to the instant litigants, but would function like a legislative rulemaker as to future parties. Because legislatures and other rulemaking bodies are not required by due process to afford a hearing to potentially affected parties, ${ }^{179}$ why should courts do so when acting in this capacity?

The Supreme Court's due process jurisprudence distinguishes between adjudicatory acts involving individualized deprivations of life, liberty, and property, and legislative enactments, which affect large groups of people. ${ }^{180}$ Whereas adjudication requires procedural safeguards, the Supreme Court made clear in Bi-Metallic Investment Co. v. State Board of Equalization ${ }^{181}$ that rights are protected from legislative deprivations by the political process. ${ }^{182}$ The distinction between adjudications and legislative enactments, however, does little to resolve the issue posed by judicial rulemakings, which are adjudications in some senses and rulemakings in others. Instead, we must look to the rationale behind the adjudication-rulemaking distinction. When a legislature passes a broadly applicable law, citizens' "rights are protected in the only way that they can be in a complex society, by their power, immediate or remote, over those who make the rule." 183 Because the electoral process affords enough protection against bad lawmaking, due process does not require the right to be heard. Such a requirement would make impossible the already difficult task of enacting legislation. But when a decision affects only a few people, electoral redress is less significant a check on bad or unfair

178. Barrett, supra note 138 , at 1053.

179. Bi-Metallic Inv. Co. v. State Bd. of Equalization, 239 U.S. 441, 445 (1915) (explaining that due process does not require individual hearings for those affected by generally applicable statutes).

180. Compare id., with Londoner v. Denver, 210 U.S. 373, 385-86 (1908) (explaining that individualized tax assessments for local improvements are adjudicatory and require notice and the opportunity to be heard).

181. Bi-Metallic Inv. Co. v. State Bd. of Equalization, 239 U.S. 441 (1915).

182. Id. at 445 (explaining that people are protected from legislative deprivations "by their power, immediate or remote, over those who make the rule").

183. Id. 
decisionmaking. In such cases, due process requires the opportunity to be heard. ${ }^{184}$ On this account, the degree to which an affected group is entitled to a hearing is inversely related to the degree of electoral control the group can potentially exert on the rulemaker.

Like generally applicable laws, precedents affect potentially very large groups of future litigants. Consequently, the sort of democratic coalition building Bi-Metallic contemplates as a means to correct an unpopular decision is possible. This, however, is where the story must end, for judicial opinions - though they may draw a broad and diverse crowd of opponents-are not readily subject to electoral change. Federal judges are, by design, rulemakers insulated from the electoral process. ${ }^{185}$ And, although there are some judicial interpretations that can be changed through the legislative process, the Cooper v. Aaron ${ }^{186}$ principle of judicial supremacy limits this to judicial interpretations of nonconstitutional law. ${ }^{187}$ Absent from judicial precedent is the crucial ingredient-feasible political redressability ${ }^{188}$ - that separates rules from adjudications in the context of due process.

2. Judicial Decisionmaking. The strength of stare decisis in the federal judiciary implicates another process: the decisionmaking process. The Constitution requires federal judicial rulemaking to take place in the context of concrete cases and controversies. This raises two concerns. First, the epistemic constraints of case-based decisionmaking inevitably lead judges to over- and underemphasize the importance of certain facts relative to the unknown facts of future cases that will come under the precedent's rule. Second, because parties in a case are most immediately concerned with winning, they have an incentive not to present information that, although it might be useful in the determination of the broader rule, is either contrary or neutral to their position in the litigation.

184. Londoner, 210 U.S. at $385-86$.

185. U.S. CONST. art. III, $\S 1$ (establishing life tenure of federal judges); see also THE FEDERALIST NO. 78, supra note 167, at 405 (arguing that "permanent tenure" is necessary for judges to serve as "bulwarks of a limited Constitution against legislative encroachments").

186. Cooper v. Aaron, 358 U.S. 1 (1958).

187. Id. at 18 ("No state legislator or executive or judicial officer can war against [the Supreme Court's interpretation of the Constitution] without violating his undertaking to support it.").

188. In a formal sense, disappointed parties have the ability to invalidate judicial interpretations of nonconstitutional, statutory law via the legislative process. But this ability is generally much more theoretical than it is practical. For an explanation of why the legislative process is often an inadequate means to overrule precedent, see infra Part III.B.3. 
a. Bad Cases Make Bad Law, But So Can Good Ones. Courtissued legal rules are products of the common law method, which, for reasons discussed below, can be a sub-optimal decisionmaking process. To understand the durability of the common law method, one must first understand the historical context in which it became a facet of American law. Writing in 1870, Oliver Wendell Holmes remarked that "[i]t is the merit of the common law that it decides the case first and determines the principle afterwards." ${ }^{189}$ At the time, many still believed in the classical conception of law-that objectively correct legal answers could be deduced from universal principles of logic and morality. ${ }^{190}$ Holmes knew better ${ }^{191}$ and the legal world is now generally disabused of the notion that positive law ultimately derives from transcendental principles of logic or morality. ${ }^{192}$ But the presumption that the resolution of cases makes for good law - the common law method, as Holmes described it - is still baked into our legal structure. The Case or Controversy Clause, ${ }^{193}$ from which the modern doctrine of standing derives,${ }^{194}$ requires that judges limit their jurisdiction to actual cases lest their opinion be merely advisory, and therefore prohibited. ${ }^{195}$ Though standing has been justified on a number of grounds, one of the most frequently invoked is the doctrine's requirement that the plaintiff allege "such a personal stake in the outcome of the controversy as to assure that concrete adverseness which sharpens the presentation of

189. Oliver Wendell Holmes, Jr., Codes, and the Arrangement of the Law, 5 AM. L. REV. 1 (1870), reprinted in 44 HARV. L. REV. 725, 725 (1931).

190. Felix S. Cohen, Transcendental Nonsense and the Functional Approach, 35 ColuM. L. REV. 809, 847 (1935) (rejecting the classical conception's view of "judicial decisions" as "products of logical parthenogenesis born of pre-existing legal principles").

191. Oliver Wendell Holmes, Jr., The Path of the Law, 10 HARV. L. Rev. 457, 460 (1897) (rejecting the idea that the law is "a deduction from principles of ethics or admitted axioms or what not").

192. See Frederick Schauer, Do Cases Make Bad Law?, 73 U. CHI. L. REV. 883, 883 (2006) ("[Holmes] fully appreciated that common law judges made law in the process of deciding cases, and nowadays few think otherwise. Common law method is not simply the discovery of immanent law, but rather an approach in which the decision of live disputes in concrete contexts guides the lawmaking function.”).

193. U.S. CONST. art. III, $\S 2$, cl. 1.

194. See, e.g., Flast v. Cohen, 392 U.S. 83, $95-98$ (1968) (explaining that "[s]tanding is an aspect of justiciability" and "[j]usticiability is the term of art employed to give expression to ... the case-and-controversy doctrine").

195. See Charles Alan Wright \& Mary Kay Kane, Law of Federal Courts 65-66 (7th ed. 2011) (noting that the prohibition against advisory opinions has been termed "the oldest and most consistent thread in the federal law of justiciability"); Letter from Chief Justice Jay and Associate Justices to President Washington (July 20,1793), in 3 CORRESPONDENCE AND PUBLIC PAPERS OF JOHN JAY 487, 488-89 (Henry P. Johnston ed., 1891). 
issues upon which the court so largely depends for illumination of difficult constitutional questions[.]"196 If courts are confined to the information presented in the instant case, the rationale goes, that information should come from parties who are sufficiently motivated to make the best arguments.

Despite the common law method's undoubted advantages, there is reason to be skeptical. The common law method relies on the notion that judges will better resolve a given legal question if they have a live controversy before them. It is only with a live controversy, the argument goes, that judges can see how a given rule plays out in real life; it "sharpens the presentation of issues." 197 Were judges free to issue opinions absent a concrete case, they might fail to consider the unpredictable ways in which a given law is actually enforced. ${ }^{198}$ Still, a case-based rulemaker is put in an awkward position. She must simultaneously resolve the immediate case and use the case's specific facts to determine a general rule to apply to similarly situated future parties. In determining the types of disputes that will fall under the rule, the facts of the immediate case create "a substantial risk that the common law rulemaker will be unduly influenced by the particular case before her." ${ }^{199}$ This concern is less pressing if the immediate case is representative of future cases falling under the rule. But if the instant case is not representative of the class of cases that will fall under the future rule, the chance that a judge will place undue importance on the facts of the present case is high. Judges "make this (mis-)assessment [of representativeness] not on the basis of a rational survey of the class, and not on the basis of systematic empirical examination, but instead largely on the basis of the usually irrelevant factors of proximity or ease of recall." ${ }^{200}$ This phenomenon, called the "availability heuristic," ${ }^{201}$ is exacerbated by the phenomenon of "anchoring,"202 through which the characteristics of the first event (a precedent-setting case, for instance)

196. Baker v. Carr, 369 U.S. 186, 204 (1962).

197. Id.

198. Cf. Abbott Labs. v. Gardner, 387 U.S. 136, 148 (1967) (explaining the doctrine of ripeness as a method to "prevent the courts, through avoidance of premature adjudication, from entangling themselves in abstract disagreements" over questions of law).

199. Schauer, supra note 192, at 894.

200. Id.

201. Id.

202. Chris Guthrie, Jeffrey J. Rachlinksi \& Andrew J. Wistrich, Inside the Judicial Mind, 86 CORNELL L. REV. 777, 790-92 (2001) (demonstrating a statistically significant influence of anchoring on judicial decisionmaking). 
influence the estimation of subsequent events (hypothetical future parties to whom the precedent will apply, for example). Consequently, even a judge who is aware that future circumstances might differ from the present case-who, in other words, is aware of the availability heuristic's influence-might be unable to escape the anchoring influence the present case has on her ability to assess the field of future disputes. $^{203}$

b. The Distortive Effect of Adversarial Information. The problems inherent in case-based rulemaking are not merely issues of framing and anchoring. The information presented in litigation is not only sometimes inadequate, but biased by design. Because parties in the adversarial context are trying to win rather than reach the best legal or factual conclusion, they are motivated to present less-thancomprehensive assessments of a given decision's legal ramifications. ${ }^{204}$ Even when litigants do not intentionally filter information in this fashion, the generalist nature of most lawyers and judges presents additional information-related concerns. Because generalist judges rely on the adversarial process to explain highly technical, specialized issues, process errors can occur when a given lawyer does not adequately understand the issue and, therefore, does not present the most relevant or reliable information. ${ }^{205}$ The resulting decision may accordingly be distorted.

As the preceding Section argues, stare decisis poses two general process problems. The first concerns due process and, specifically, the preclusive effect stare decisis has on parties' ability to fully present their claims. The second concerns the judicial decisionmaking process and, in particular, the distortive effects of case-based decisionmaking and adversarial information. Though perhaps an unlikely hero, Rule

203. Schauer, supra note 192 , at 897.

204. See, e.g., William A. Klein, Tailor to the Emperor with No Clothes: The Supreme Court's Tax Rules for Deposits and Advance Payments, 41 UCLA L. REV. 1685, 1725 (1994) (noting that lawyers in tax cases tend to "focus[] on traditional [precedential] arguments" because they have "no incentive to offer fundamental analysis, a new approach, or a critique of the existing set of rules").

205. See Bernard Wolfman, The Supreme Court in the Lyon's Den: A Failure of Judicial Process, 66 CORNELL L. REV. 1075, 1075 (1981). Wolfman explains:

Hardly an enclave of tax experts, the Supreme Court relies for illumination and protection on the validity of a basic assumption of the adversary process: that strong and effective advocates bring the issues into focus and marshal the strongest arguments for each side, thus educating the Court and helping it reach the best result. 
24(a)(2) - unfettered by Article III standing - has the ability to greatly reduce the effect of these process problems.

\section{INTERVENTION AS A REMEDY}

In light of the problems outlined in Part II, commentators have proposed a more flexible approach to stare decisis ${ }^{206}$ or a system of notice-and-comment judicial rulemaking. ${ }^{207}$ There is much to be said for these and other proposals, but they would require federal legislation, a reconception of stare decisis, or both. As luck would have it, a far more practical remedy already exists in the Federal Rules of Civil Procedure: Rule 24(a)(2).

\section{A. Rule 24(a)(2) and Stare Decisis's Process Errors}

First, as discussed above at Part II.B, the preclusive effect of stare decisis can constrain a litigant's ability to argue certain issues such that, in some cases, one's right to a hearing seems like an empty formality. Rule 24 mitigates this effect by allowing parties who will potentially be subject to a given decision's precedential effect to intervene and influence the result. ${ }^{208}$ For instance, imagine that a court is interpreting the government's application of the Sherman Antitrust Act to a manufacturer (Graft Foods) and a retailer (Fraud Meyer) who entered into a vertical agreement to fix a minimum resale price for a certain macaroni product. The Sherman Antitrust Act's text empowers the government to prohibit "[e]very contract, combination . . . or conspiracy[] in restraint of trade, ${ }^{209}$ and asks that federal courts determine the types of behavior that fall under the Act's prohibition. ${ }^{210}$ Vertical price restraints can be seen as a practice that inhibits ${ }^{211}$ or

206. See Barrett, supra note 138, at 1060-61 ("Without flexibility, stare decisis functions as a doctrine of preclusion, and its application to nonparty litigants poses the same due process problem as the application of issue preclusion to nonparty litigants.").

207. See Abramowicz \& Colby, supra note 128, at 967-68 (arguing that "[a]lthough it would represent a significant change," it seems "the case for notice-and-comment judicial decisionmaking is in most respects at least as strong as the case for notice-and-comment administrative rulemaking").

208. For cases in which courts have recognized adverse stare decisis effect as a cognizable interest under Rule 24(a)(2), see supra note 47.

209. 15 U.S.C. $\$ 1$ (2012).

210. See Nat'l Soc'y of Prof'l Eng'rs v. United States, 435 U.S. 679, 688 (1978) ("The legislative history makes it perfectly clear that [Congress] expected the courts to give shape to the [Sherman Act's] broad mandate by drawing on common-law tradition.").

211. See Dr. Miles Med. Co. v. John D. Park \& Sons Co., 220 U.S. 373, 384-85 (1911) (banning vertical price restraints because they are anticompetitive). 
sometimes promotes ${ }^{212}$ trade depending on the context, so the case could go either way. That is, the court could create a per se rule against vertical price restraints or create a more flexible standard that permits them when they are effectively procompetitive. Many industries comprising many parties will be affected by this ruling; vertical price restraints are not exactly a niche practice. ${ }^{213}$ In this scenario, a straightforward application of Rule 24(a)(2) would entitle other companies to defend their interests by participating in the litigation. These parties, much like the intervenors in Grutter v. Bollinger, ${ }^{214}$ might very well make arguments that Graft Foods and Fraud Meyer have incentives not to make. ${ }^{215}$ Or perhaps vertical price restraints are not as important in the macaroni industry as they are in other sectors. Were this the case, Graft Foods might not argue the case as vigorously as would a company more significantly affected by a potentially adverse precedent. Requiring Article III standing would likely preclude many of these intervenors from defending their interests. Unlike under Rule 24(a)(2), an adverse stare decisis effect does not count among the injuries that satisfy Article III standing. ${ }^{216}$ A party alleging stare decisis harm can intervene only if Article III does not apply to Rule 24(a)(2).

It is important to note that Rule 24(a)(2) intervention can protect the interests of future litigants even when they themselves do not intervene. The greater the number of parties in the precedent-setting litigation, the greater the chance that one of the parties will anticipate the interests of future litigants. For instance, in the example above, if Shady Records, Inc. is allowed to intervene in the Graft Foods litigation, the interests of future music publishers will, in theory, be

212. See Leegin Creative Leather Prods., Inc. v. PSKS, Inc. 551 U.S. 877, 906-07 (2007) (overruling Dr. Miles's per se ban on vertical price agreements because they can be efficient).

213. For instance, Apple, Inc. was recently required to pay a $\$ 450$ million settlement in a price-fixing scheme involving e-book publishers selling on the iTunes platform. See Brian X. Chen \& Nicole Perlroth, Settlement in Apple Case Over E-Books is Approved, N.Y. TIMES (Nov. 21, 2014), https://nyti.ms/2ts2V7Q [https://perma.cc/3VQG-LJMY].

214. Grutter v. Bollinger, 188 F.3d 394, 397 (6th Cir. 1999).

215. For a description of the intervenors, see supra note 19.

216. Such an injury would likely not be the "concrete," "distinct and palpable," or "actual and imminent" injury required by standing. McConnell v. FEC, 540 U.S. 93, 225 (2003), overruled on other grounds by Citizens United v. FEC, 558 U.S. 310 (2010); see also Deutsche Bank Nat. Tr. Co. v. FDIC, 717 F.3d 189, 195 (D.C. Cir. 2013) (Silberman, J., concurring) (arguing for application of Article III standing to intervenors as a means to avoid intervention by parties with "a concern with a possible unfavorable precedent"); 13A WRIGHT \& MILLER, supra note 83, $\S 3531.4$, at 138-295 (noting no decision in which adverse stare decisis effect was a sufficient injury to confer standing). 
protected better than if Shady Records were excluded. Though this is no substitute for the right to be heard on one's own claims, this sort of virtual representation at least softens stare decisis's blow.

Similarly, Rule 24(a)(2) potentially ameliorates the rule-distorting effects of case-based adjudication, as discussed above in Part II.B.2. Although judges may still be influenced by the availability heuristic, the ability of other affected parties to intervene decreases the odds that the availability heuristic will lead judges to misconstrue the class of litigants to whom the rule will apply. In other words, as the number of parties increases, so too does the degree to which the instant parties represent the class of people who will later be affected by the decision's precedent. The effect of anchoring is similarly mitigated insofar as the characteristics by which judges assess the possible class of future litigants will be more representative of the class of people affected by the decision. And, lest judges be concerned that intervening parties will hijack the litigation, Rule 24(a)(2) allows judges the ability to limit the intervening parties' activities. ${ }^{217}$

The benefits of allowing intervention under Rule 24(a)(2) without requiring Article III standing are even clearer when one considers how stare decisis affects the federal judiciary's legitimacy. The rest of this Note considers this relationship and evaluates the alternatives available to would-be intervenors.

1. Rule 24(a)(2) and Legitimacy. Rule 24(a)(2)'s enhancement of the rulemaking process implicates a related judicial value: legitimacy. As Alexander Hamilton recognized in Federalist No. 78, the federal judiciary has "no influence over . . . the sword or the purse." 218 Consequently, as the Supreme Court has recognized, the federal judiciary's "power lies ... in its legitimacy." 219 The public's perception of the judiciary's legitimacy is determined by a number of factors, foremost among them the degree to which a court's decisions and procedures comport with the public understanding of procedural justice. ${ }^{220}$ Whether members of the general public consider a given legal decision procedurally just turns in large part on whether they feel they "have an opportunity to state their case to legal authorities" or

217. For a discussion of courts' authority to limit intervenors' activity, see supra notes 112113 and accompanying text.

218. THE FEDERALIST No. 78, supra note 167, at 402.

219. Planned Parenthood of Se. Pa. v. Casey, 505 U.S. 833, 865 (1992).

220. Tom R. Tyler, Does the American Public Accept the Rule of Law? The Findings of Psychological Research on Deference to Authority, 56 DEPAUL L. REV. 661, 663 (2007). 
otherwise "have a 'voice' in the decision-making process." 221 When a court renders a legal decision on the basis of arguments or facts never presented by the instant parties - in other words, when a court applies precedent-it loses legitimacy in the eyes of the instant parties insofar as they feel denied the right to be heard. ${ }^{222}$

Though again not a perfect remedy, Rule 24(a)(2) allows parties who will be affected by a given precedent to intervene and defend their interest. Rule 24 gives these parties the right to be heard where they otherwise would not be. In addition, to the extent that Rule 24 encourages potentially affected parties to intervene, interests akin to those of all potential future parties - whether or not they personally had the opportunity to intervene-are more likely to have been represented when the precedent was set. Moreover, by increasing the court's exposure to different sources and greater volumes of information, Rule 24 also helps ensure the court's decision was not made on the basis of faulty, misrepresentative, or inadequate data. The greater likelihood that a court's decision is based on all of the relevant data, in turn, increases the public's confidence in the decision's fairness, and thus the court's legitimacy. And the sounder the decision, the less likely it is to be overruled, which similarly increases the court's legitimacy. ${ }^{223}$

\section{B. The Inadequacy of Alternative Remedies}

The argument for Rule 24(a)(2) intervention uninhibited by Article III standing would be considerably less powerful if existing procedural remedies adequately accommodated the needs of third parties and the decisionmaking process. When one considers Rule 24's alternatives, however, the case for intervention of right becomes even clearer.

221. Id. at 664 .

222. Against this argument is the standard account of stare decisis as a guardian of a court's legitimacy. See, e.g., Casey, 505 U.S. at 866 ("The legitimacy of the Court ... fade[s] with the frequency of its vacillation."). But these arguments-one for representation and the other for stare decisis - are not mutually exclusive. The best way to accommodate both interests might be to allow interested parties to intervene in a case so that the resulting precedent better accommodates the interests of future parties it binds.

223. See id. (arguing that frequent judicial inconsistency is perceived as "evidence that justifiable reexamination of principle had given way to drives for particular results in the short term"). 
1. The Amicus Curiae Brief. Rule 24 intervention only operates at the trial level. ${ }^{224} \mathrm{~A}$ party permitted to intervene at the trial level will continue to be treated as an original party through the course of any appeal, ${ }^{225}$ but a party cannot intervene at the appellate level. By contrast, parties interested in the resolution of an appellate case who were not part of the original litigation can submit an amicus curiae brief. ${ }^{226}$ Because amicus briefs do not require the same degree of involvement at the trial stage but nevertheless can play a role at the appellate level-where substantive precedential law is made-a reasonable case can be made that amicus briefs are a preferable alternative to intervention from the perspective of a would-be intervenor. And federal judges would almost certainly prefer to deal with multiple amici than multiple parties on each side of the litigation.

But the ease of filing an amicus brief is, in part, its undoing. Parties are not entitled to file amicus briefs at will, but instead may do so only when the court or both parties consent. ${ }^{227}$ Getting consent to file an amicus brief only gets you so far. District and appellate courts rarely cite amici, and many judges consider them to be an improper addition to the record. ${ }^{228}$ Others, such as Judge Posner, view amicus briefs as inefficient and suspect that they are intended as "an end run around court-imposed limitations on the length of parties' briefs." 229 Sometimes it is not clear that judges read amicus briefs at all. For instance, after his dissent in Frank v. Walker, Judge Posner defended his seeming reversal of his position from Crawford v. Marion County Election Board on the grounds that Crawford was written before he

224. The Federal Rules of Civil Procedure only govern federal district courts. See FED. R. CIV. P. 1 ("These rules govern the procedure in all civil actions and proceedings in the United States district courts...."). The Federal Rules of Appellate Procedure do not have an intervention rule analogous to Rule 24 of the Federal Rules of Civil Procedure.

225. See Diamond v. Charles, 476 U.S. 54, 64 (1986) ("Had the State sought review ... Diamond, as an intervening defendant below, also would be entitled to seek review, enabling him to file a brief on the merits, and to seek leave to argue orally.").

226. See FED. R. APP. P. 29.

227. See FED. R. APP. P. 29(a)(2) ("Any other amicus curiae [than those filed by the government] may file a brief only by leave of court or if the brief states that all parties have consented to its filing.").

228. Linda Sandstrom Simard, An Empirical Study of Amici Curiae in Federal Court: A Fine Balance of Access, Efficiency, and Adversarialism, 27 REV. LITIG. 669, 686, 695 (2008).

229. Voices for Choices v. Ill. Bell Tel. Co., 339 F.3d 542, 544 (7th Cir. 2003). But see Justice Breyer Calls for Experts To Aid Courts in Complex Cases, N.Y. TIMES, Feb. 17, 1998, at A17 ("[Amicus] briefs play an important role in educating judges on potentially relevant technical matters, helping to make us not experts but educated lay persons and thereby helping to improve the quality of our decisions."). 
knew the true nature of voter identification laws. ${ }^{230}$ Specifically, Judge Posner had not yet realized that, given no actual evidence of voterimpersonation fraud, voter identification laws were "a mere fig leaf for efforts to disenfranchise voters likely to vote for the political party that does not control the state government," ${ }^{231}$ as he would later put it in Frank v. Walker. But Judge Posner must not have done his homework: the Brennan Center for Justice filed an amicus brief in the 2007 Crawford litigation that demonstrated, among other things, that "there is no evidence of impersonation fraud in Indiana," 232 that "not a single Indiana resident has ever been indicted for impersonation fraud,"233 and that the study the district court relied on to uphold the voter identification law itself recognized that "wrongful disenfranchisement of voters is a 'far bigger problem' than voter fraud." 234 A person who files an amicus brief, it would seem, is a person who runs a substantial risk of being ignored.

Perhaps the likelihood of being ignored is actually a merit of the amicus brief. Judges too often rely on dubious amicus facts without independently confirming their accuracy. For instance, in Caperton $v$. A.T. Massey Coal Co. ${ }^{235}$ the Supreme Court had to determine whether the Constitution was violated when a state judge failed to recuse himself in a case involving a party who had spent $\$ 3$ million on the judge's reelection campaign. ${ }^{236}$ Dissenting from the majority, Chief Justice John Roberts argued that the contribution did not violate due process, citing an amicus brief for numerous "examples of judicial elections in which independent expenditures backfired and hurt the candidate's campaign."237 The amicus brief cited a law review article, which itself had cited an email from a state judge that was "'on file with' the authors." "238 Similarly, in Florence v. Board of Chosen Freeholders, ${ }^{239}$ many of the factual claims referenced in the majority

230. See Posner, supra note 14.

231. Frank v. Walker, 773 F.3d 783, 788 (7th Cir. 2014) (Posner, J., dissenting).

232. Brief for the Brennan Center for Justice as Amicus Curiae Supporting PlaintiffsAppellants at 2, Crawford v. Marion Cty. Election Bd., 472 F.3d 949 (7th Cir. 2007) (Nos. 06-2218, 06-2317).

233. Id. at $7-8$.

234. Id. at 9 .

235. Caperton v. A.T. Massey Coal Co., 566 U.S. 868 (2009)

236. Id. at 872 .

237. Id. at 901 (Roberts, C.J., dissenting).

238. Allison Orr Larsen, The Trouble with Amicus Facts, 100 VA. L. REV. 1757, 1785 (2014).

239. Florence v. Bd. of Chosen Freeholders, 566 U.S. 318 (2012). 
opinion and cited to in an amicus brief were not actually supported by any authority in the brief. ${ }^{240}$ Frighteningly, these cases are not rare, isolated incidents. ${ }^{241}$

Rule 24(a)(2) intervention shares none of these disadvantages. First, Rule 24(a)(2) enables intervention of right, which, at least in theory, is a right a judge cannot discretionarily deny if the intervenor satisfies Rule 24(a)(2)'s conditions. Second, because the information presented at trial by intervenors is the record, judges are considerably more likely to take intervenors' arguments and data seriously. As an upshot of being taken seriously, intervenors' arguments and data are more likely to be cross-examined by opposing counsel. Consequently, dubious data, of the sort sometimes found in amicus briefs, are less likely to enter the judicial decisionmaking calculus. In the status quo, by contrast, the perception of amicus briefs as unimportant serves as a disincentive to contest their facts. Even if a lawyer is inclined to contest opposing counsel's amicus facts, the sheer volume of amicus briefs at some levels of litigation makes this task nearly impossible. ${ }^{242}$ Intervention also offers tactical advantages amicus briefs cannot. For instance, parties intervening at the trial level have the ability, just like an original party, to preserve certain issues for appellate review. ${ }^{243}$ Amicus briefs, on the other hand, can only respond to issues preserved by the parties on appeal. ${ }^{244}$ Thus, parties who seek to shape the contours of a given judicial rule should prefer intervention to participation as an amicus.

2. Permissive Intervention under Rule 24(b). Federal Rule of Civil Procedure 24(b) enables judges to grant intervention permissively rather than of right. The requirements imposed by Rule 24(b) are significantly less demanding than those in Rule 24(a)(2). In contrast to Rule 24(a)(2)'s tripartite requirement, Rule 24(b) asks only whether

240. Larsen, supra note 238, at 1785.

241. See id. at 1757-1800 (discussing cases in which the Supreme Court has relied on dubious amicus facts).

242. See id., at 1764 ("The number of amicus briefs filed [in the Supreme Court] and the amount of seemingly legitimate information available to present makes it very unlikely that a litigant can adequately respond to amici-presented factual claims.").

243. This is an upshot of intervenors' presumptive status as full parties to the litigation. See supra note 108 and accompanying text. Critically, however, an intervenor cannot actually appeal unless she has Article III standing. See Diamond v. Charles, 476 U.S. 54, 63 (1986) (noting that "status as a 'party' does not equate with status as an appellant").

244. See, e.g., Eldred v. Ashcroft, 255 F.3d 849, 852 (D.C. Cir. 2001) (Sentelle, J., dissenting) ("There is no dispute that an amicus curiae may not raise new issues on appeal."). 
the applicant has a "conditional right to intervene by a federal statute" 245 or "a claim or defense that shares with the main action a common question of law or fact." 246 Unlike Rule 24(a)(2), however, Rule 24(b) does not grant a right. Apart from the requirement that the intervenor share a claim of law or fact, the action under Rule 24(b) is entirely at the judge's discretion. ${ }^{247}$ It is unlikely that a court that applies Article III standing to Rule 24(a)(2) intervention for prudential reasons would open suits up to Rule 24(b) intervenors. ${ }^{248}$

Furthermore, the arguments for applying Article III standing to Rule 24(a)(2) intervention of right apply equally to permissive Rule 24(b) intervention. A permissive intervenor is just as much "on an equal footing" 249 as a Rule 24(a)(2) intervenor, and would similarly destroy Article III jurisdiction according to the Eighth Circuit's reasoning. ${ }^{250}$ Because a Rule 24(b) intervenor presumably has a less significant interest in the litigation than a Rule 24(a)(2) intervenorotherwise they would have attempted to intervene under Rule 24(a)(2) $)^{251}$ - Rule 24(b) intervenors are also more likely to turn courts into "judicial versions of college debating forums." ${ }^{52}$ Accordingly, circuits using Article III standing as a prudential barrier would presumably be less likely to allow intervention under Rule 24(b) than under Rule 24(a)(2).

3. The Democratic Process. The Supreme Court's standing cases make clear that the constitutionally preferred method of redressing

245. FED. R. CIV. P. 24(b)(1)(A).

246. FED. R. CIV. P. 24(b)(1)(B).

247. See 7C WRIGHT \& MILLER, supra note 31, § 1902, at 261 ("An application for permissive intervention is addressed to the discretion of the court, whereas an application for intervention of right seems to pose only a question of law.").

248. But see Flynt v. Lombardi, 782 F.3d 963, 967 (8th Cir. 2015) (allowing an intervenor without standing under Rule 24(b) because he only sought to unseal legal documents).

249. City of Cleveland v. Nuclear Regulatory Comm'n, 17 F.3d 1515, 1517 (D.C. Cir. 1994).

250. Mausolf v. Babbitt, 85 F.3d 1295, 1300 (8th Cir. 1996) ("[A]n Article III case or controversy, once joined by intervenors who lack standing, is - put bluntly - no longer an Article III case or controversy."). But see Flynt, 782 F.3d at 967 (allowing an intervenor who did not have standing).

251. In reality, Rule 24(b) is used by litigants as a fallback to Rule 24(a)(2). See 7C WRIGHT \& MiLLER, supra note 31, § 1902, at 262 ("Applicants often will rely alternatively on both subdivision (a) and subdivision (b) and courts sometimes hold that intervention will be allowed without specifying which branch of the rule is on point.").

252. Mausolf, 85 F.3d at 1301 (quoting Valley Forge Christian Coll. v. Ams. United for Separation of Church \& State, Inc., 454 U.S. 464, 473 (1982)). 
generalized grievances is the electoral process. ${ }^{253}$ This approach makes sense for the majority of generally applicable legislative rules. But as it concerns generally applicable judicial rules, democratic redressability is an implausible remedy. Legislative gridlock precludes many a statutory amendment at the federal level, ${ }^{254}$ even if this might not be as significant a concern at the state level. ${ }^{255}$ Parties who overcome the substantial obstacle of gridlock may yet meet an insuperable one: according to the judicial supremacy principle articulated in Cooper $v$. Aaron, federal courts' interpretation of the Constitution is the Constitution, and therefore not subject to legislative or executive second-guessing. ${ }^{256}$ In many cases, either for political or constitutional reasons, the political process will not afford an effective remedy to a party wishing to change precedent.

Considering the alternatives to Rule 24(a)(2) - that is, the amicus brief, Rule 24(b), and the democratic process -intervention of right is likely the most plausible way to mitigate the process errors of stare decisis. Rule 24(a)(2) can only play this role, however, if parties who seek to use it are not required to demonstrate independent Article III standing.

\section{CONCLUSION}

Stare decisis requires that decisions issued by federal courts be followed by litigants further down the pike. Whether this is a merit or fault of our judicial system is an open question. There is certainly value, for courts and society more generally, in a system of stare decisis that "promotes the evenhanded, predictable, and consistent development of legal principles." ${ }^{257}$ It is hard to imagine how society could function

253. See, e.g., Warth v. Seldin, 422 U.S. 490, 508 n.18 (1975) ("[C]itizens dissatisfied with provisions of [generally applicable laws] need not overlook the availability of the normal democratic process.").

254. See SARAH Binder, PolARIZED We Govern? (2014), https://www.brookings.edu/wpcontent/uploads/2016/06/BrookingsCEPM_Polarized_figReplacedTextRevTableRev.pdf

[https://perma.cc/ZGL2-WREZ] (noting, among other things, that the 2011-2012 Congress was the most gridlocked in the postwar era).

255. See 2016 State \& Legislative Partisan Composition (Pre-Election), NATIONAL CONFERENCE OF STATE LEGISLATURES, http://www.ncsl.org/Portals/1/Documents/Elections /Legis_Control_2016_Nov7.pdf [https://perma.cc/DQM9-WBQM] (showing that the majority of state governments are not divided).

256. Cooper v. Aaron, 358 U.S. 1, 18 (1958) ("No state legislator or executive or judicial officer can war against [the Supreme Court's interpretation of the Constitution] without violating his undertaking to support it.").

257. Payne v. Tennessee, 501 U.S. 808, 827 (1991). 
otherwise: the rule of law could hardly take root in an amnesic judiciary, in which courts would be free to determine legal principles afresh in some Kafkaesque judicial version of Groundhog Day. ${ }^{258}$ But the impulse to "treat[] like cases alike"259 should not lead us to ignore two other important judicial values: accuracy and fairness. Stare decisis promotes the values of consistency, efficiency, and fairness it was designed to advance. At the same time, it has the potential to force reliance on suboptimal precedent and to deny parties the ability to be heard to the same extent as those who are first to litigate an issue.

Although hardly a cure-all, Rule 24(a)(2) mitigates stare decisis's process issues. Under Rule 24(a)(2), a party whose interest will potentially be impaired by a given case's stare decisis effect has the ability to intervene and so influence the result. Even when a future party cannot intervene itself, the probability that an intervenor's interests will anticipate - and in a sense represent - those of the future party increases under Rule 24(a)(2). Perhaps more important, Rule 24(a)(2) intervention potentially increases the quality of judicial decisionmaking by increasing the amount of information and number of perspectives represented in a given case. Conveniently, Rule 24(a)(2) also provides a court the ability to limit the scope of an intervenor's participation, allowing judges to exploit the Rule's informative benefits while limiting procedural complication.

Requiring that intervenors satisfy Article III standing robs parties and the federal judiciary of these potential benefits. It would be one thing if Article III clearly applied to Rule 24(a)(2). The Constitution has stood in the way of change before-that, fundamentally, is its purpose. But the use of Article III standing to bar intervention once a justiciable case or controversy has been established is an extraconstitutional use of the doctrine. In any event, it is a cruder-thannecessary tool to address the "floodgates" concern expressed by the Seventh, Eighth, and D.C. Circuits.

The Brennan Center did not move to intervene in Crawford, and it is far from clear that its intervention would have changed the outcome of the case. But regardless of one's views on the merits of voter identification laws, surely we would all prefer a judicial system in which some of our most esteemed federal judges did not regret-and blame on inadequate information - their most significant decisions.

258. Groundhog Day (Columbia Pictures Corp. 1993).

259. Hart, supra note 133, at 264. 